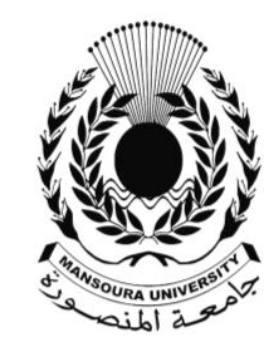

جامعة المنصـورة المعاني

$$
\text { كليـة الآداب }
$$

\title{
اتجاهات الفروق بين الجنسين في التوجه الإيجابي نحو الحياة "دراسة عاملية"
}

\author{
دكتور/ ناصر بن علي العريفي \\ أستاذ علم النفس المساعد \\ كلية الملك فهر الأمنية
}

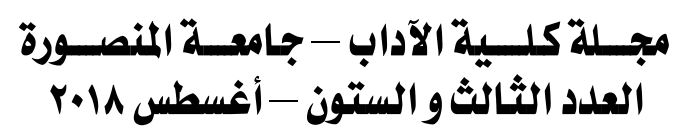




\section{اتجاهات الفرووق بين الجنسين في النوجه الإيبابي نهو اليياة \\ "دراسة عاملية"}

د/ ناصر بن علي العريفي

هدفت الدراسة إلى الكثف عن الفروق الجوهرية بين الجنسين في التوجه الإيجابي نحو الحياة، كما هدفت إلى التعرف إلى الفروق بين

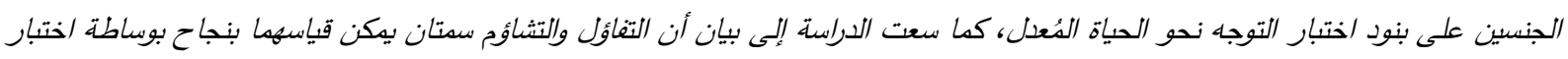

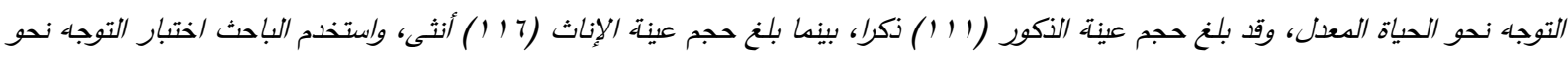

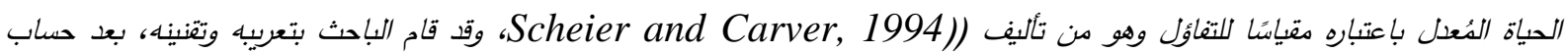

$$
\text { الخصائص السيكومترية للاختبار، والتأكد من صلاحيته للتطبيق الميداني. }
$$

وقد كثفت النتائج عن وجود فروق جوهرية دالة لصالح الذكور عند مستوى (1. ...)، في متغير التوجه الإيجابي نحو الحياة، كما

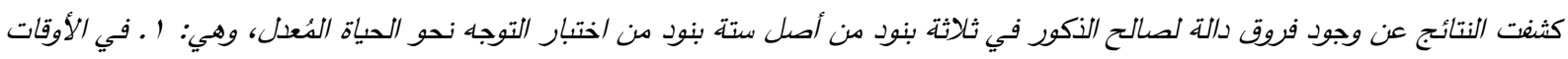

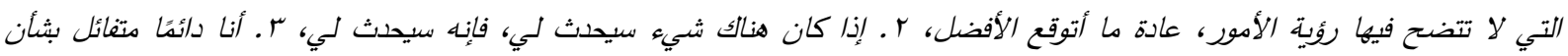

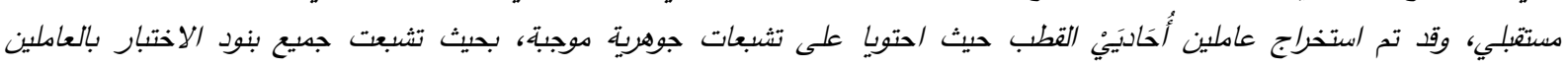

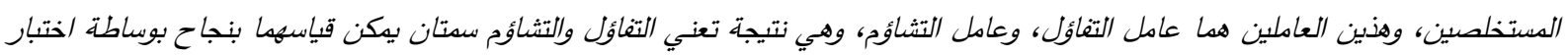

\section{Abstract}

$$
\text { التوجه نحو الحياة المعدل، ونتائج التحليل العاملي للأداة بهذا تعني أن التفأول والتثاؤم سعتان مستقلتان، ولكنهما مترابطتان. }
$$

The study aimed at revealing the significant differences between the two genders in terms of the positive life orientation, and identifying the differences between the two genders on the items of the modified Life Orientation Test (LOT). In addition, the study sought to demonstrate that optimism and pessimism are traits that can be successfully measured by means of the modified LOT. The study sample size is 111 males and 116 females. The researcher used the modified LOT (Scheier and Carver, 1994) as a measure of optimism. The researcher localized and legalized the test, after testing the psychometric properties of it and ensuring its suitability for field application.

The findings indicated that there are significant differences in favor of males at (0.01) in the positive life orientation. Further, the findings indicated that there are significant differences in favor of males in three out of six items of the modified LOT, i.e.: 1) In uncertain times, I usually expect the best; 2) If something can go wrong for me, it will; 3) I'm always optimistic about my future. Two unipolar factors, i.e. optimism and pessimism, which have positive substantial saturation, were extracted. All test items were satiated with the two factors extracted, which means that optimism and pessimism are traits that can be successfully measured by means of the modified LOT. Hence, the findings of factor analysis of the instrument indicate that optimism and pessimism are independent but related traits.

أسفرت عنه هذه الحرب من اضطرابات نفسية

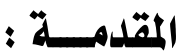

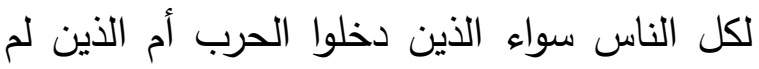

يدخلوها، في هذا الوقت تجلى اهتمام علم النفس

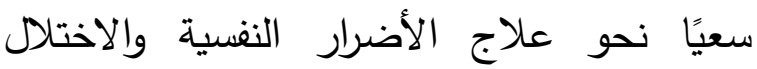
الوظيفي الذي حدث من جراء تلك الحرب. لقد اعداج تركز الاهتمام على علاج المرض، وتجاهل تماءيًا

فكرة الانتباه للفرد القادر على الإنجاز وتحقيق

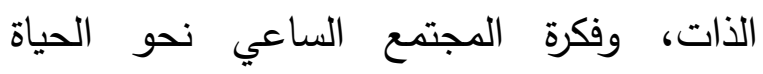

والارتقاء، لم يستطع علم النفس وهو يعالج
لعلم النفس خُطى مهمة ذات معنى ودلالة

في حياة الناس الذين يعانون من مشاكل عقلية خطيرة، لكن اهتمامات علم النفس نحو مساعدة الناس في أن يصبحوا أكثر صحة وأكثر سعادة الفئمات وغير ذلك - تلك الاهتمامات- كان انتباه علم النفس لها قليلاً نسبيًا (Roherer,2005)

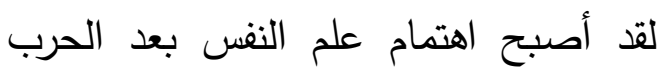

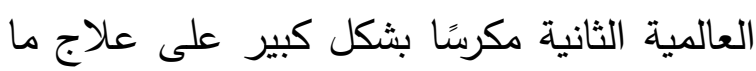


إن مجــال علــم الــنفس الإيجـابي علــى المستوى الذاتي يـدور حول الخبرات الذاتيـة ذات القيمـة مثثل: حسـن الحسال well-being، والقناعـة

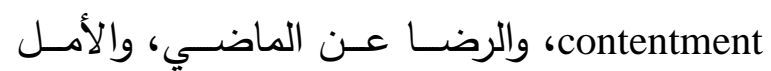

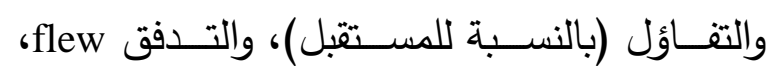
والسـعادة (في الحاضـر)، وعلى المستوى الفردي يهتم هذا المجال الجديد بالسمات الفردية الإيجابية مثل القدرة على الحب والعمل والثجاعة والمهارة

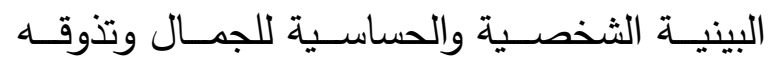
والمثابرة والصـفح والأصـالة، والذهنيـة المستقبلية

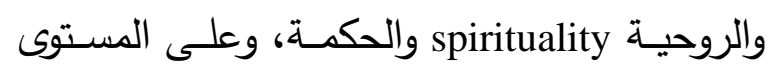

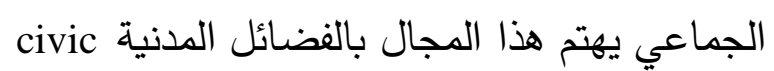
والمؤسسـات التـي مـن شـأنها أن تـدفع لــ virtues

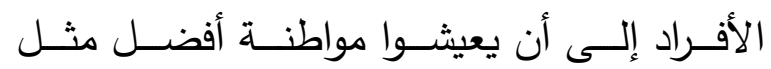

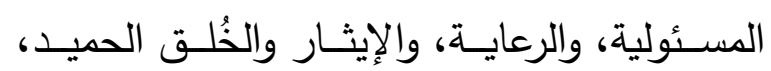

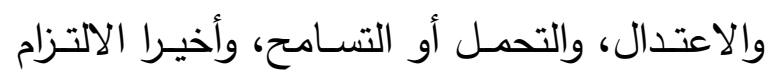

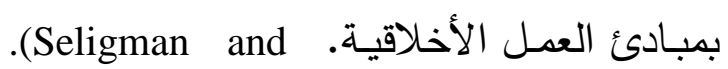
Mihaly, 2000) إن علم النفس الإيجابي ليس أحد الكماليات أو أوجها الرفاهية التي يعود نفعها على الأثريـاء،

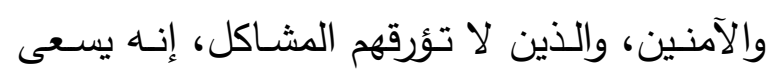
لفهم وبناء ثلاثة أنواع من الحياة: الحياة السعيدة، الحياة الجيدة، الحياة ذات المعنى، وهنـاك بعض وله جوانب هذه الأنواع من الحياة (وليس عددًا منها) يعيشها هؤلاء الذين لا يشعرون بالألم: مثل طعم

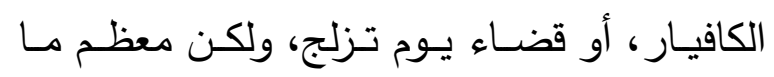
يقدمـهـ علم النفس الإيجـابي هو لنـا جميعـا: مـن يشعرون بالراحة، ومن تؤرقهم المتاعب، والمرفهون والمعدمون، والمرضى. (Seligman, 2003)
المرضى محاولا حل مشكلاتهم بالعلاج النفسي، أن يتتبه إلى فكرة أن بناء القوة وتمكين البشر هو هول السلاح الأكثر قوة والأكثر فعالية في ترسانة (Seligman, 2002). العلاج النفسي arsenal ومسع الوقت بدأ علم النفس يهتم لا بعـلاج المرض النفسي فقط وكيفيـة مسـاعدة الناس على تخطـي أزمـتهم النفسـية، ووضــعهم علـى أرض صلبة يمكنهم بعدها أن يمارسوا حياتهم بعد الخلل

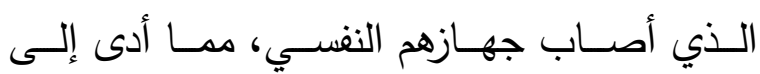
اعتلالهم نفسيًا، بل بدأ يهتم إلى جوار ذلك بكيفية جعـل النـاس يثـعرون بالرضـا عـن الحيـاة، وأن يكونـوا أكثر تفـاؤلا، وأكثر تسـامحًا وتجـاوزًا عـن بـن السيئات، وغيـر ذلك. وبـدأ يطفو على السـطح موضوعات جديدة لم يكن يتطرق إليها علم النفس مسن قبـل، وبـدأت اهتمامـات علمـاء النفس أمثال سـنايدر ، وسـيلجمان، ومـا يكـل فـورديس وكـلاي توكر ، وغيرهم كثير ، تتجه نحو موضوعات الأمل والتفاؤل والسعادة وحب الحياة والتسامح ومساعدة

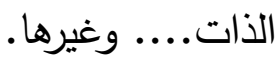
ولعـل عـام (991 1 ) يُعـد أهـم الأعـوام في وني تاريخ علم النفس، وهو العام الذي كان فيه (مارتن سـيلجمان) رئيسًــا لرابطـة علـم الـنفس الأمريكيـة (APA) وهو العام الذي ظهر فيه مـا يُسمى بعلم

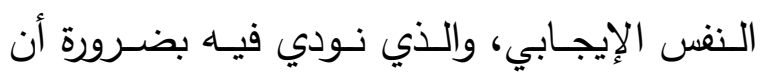

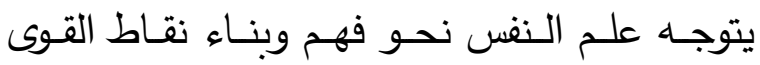
الإنسـانية، وذلك لاسـتكمال التأكيد على عـلاج

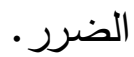

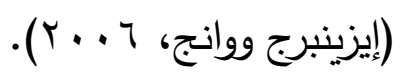


؛ (الحفن

(Y0) كما عُرف إضـافة لمـا سبق أنـه "اتجاه من جانب فرد ما نحو الحياة أو نحو أحداث معينة، يميل أحيانا إلى حد مفرط للعيش على الأمل، أو نحو التركيز على الناحيـة المشرقة من الحياة أو الأحداث أو الجانب المفعم بالأمـل والخير ، وهو اتجاه عـام جدًا أو سمة شخصية ترى الخير في معظم الأشياء والأحداث وتتوقع أن تكون العواقب

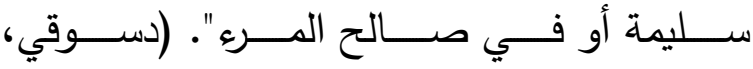

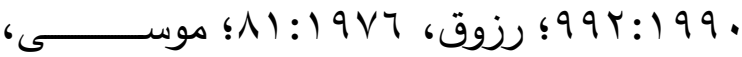
$\cdot(1 \wedge 7: Y \cdot 1$

كما عُرف بأنـا "التوقعات الذاتيـة الإيجابيـة عن المستقبل الشخصسي للفرد " (Stipek, 1981)؛ وهو" استعداد شخصسي للتوقع الإيجابي للأحداث (Marshall, et al., 1992)، وكذلك عُرف بأنه: " نظرة استبثـار نحو المستقبل تجعل الفرد يتوقع حدوث الأفضل، وينتظر حدوث الخير ، ويرنوا إلى النجاح ويستبعد ما خلا ذلك". (عبـد الخـالق، 997 (:7 ؛ الأنصــاري، ("I"Y . r r

كما عُرف بأنه " ميل أو رغبة لتوقع أفضل (Huitt, " النتائج الممكنـة للأفعال أو الأحداث 1996, 2005، وعُرف أيضـا بأنه " حالة وجدانية لـدى الفـرد في توقعـه للخيـر والأمـل لمجريـات الأحداث الحالية والمستقبلية، وهذه الحالة وقتية أو مستديمة اعتمـادًا على الأحداث الحاليـة وخبـرات الفرد السابقة ". (مراد وأحمد، . . . ب).

\section{الإطار النظري للدراسة :}

نظرًا لأن اختبار التوجه نحو الحياة المعدل

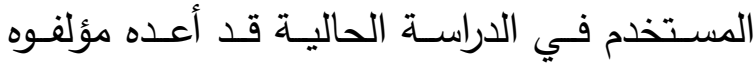
باعتباره مقياسًا للتفـاؤل، لذا ينبغي التعـرف إلى بعض المعاني المتعددة للتفاؤل، ثم نتتاول تعريف التوجـهـ الإيجـابي نحــو الحيـاة كمـا أعـده معـدوا الاختبار ، وذلك كما يلي:

للتفاؤل تعريفات متعددة لا يمكن القول بأنها متباينـة إلى حد بعيد، فقد ورد تعريفه - لغويًا في عدد من المعاجم العربية والأجنبية، كما وردت لله تعريفات أخرى من منظور علم النفس، وفيما يلـي نكتفـي بعـرض بعـض التعريفـات اللغويــة والسيكولوجية للتفاؤل، وذلك على النحو التالي:

\section{أولاً : تعريف التفاؤل في اللفة العربية :} في باب الفاء عُرِّف التفاؤل كما يلي:

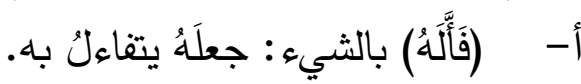

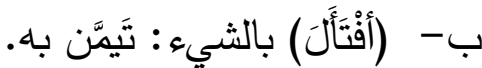

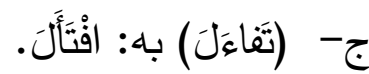
د- - دَفأَّنَ) به: مطاوع فألَّهُ.

هـ-(الفأْنُ): قول أو فعل يستبشر به. (أنيس، (TV) : ) $9 V T$

\section{ثانيا : التعريف النفسي أو الاصطلاحي للتفاؤل}

عُرَّف التفـاؤل بأنــه: "اتجـاه إزاء الحيـاة، أو إزاء أحـــاث معينـة، ينـزع الفـرد فيـــه إلـى رؤيــة

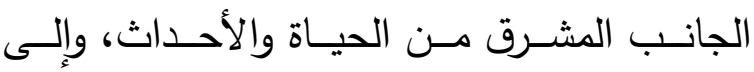
الإيمان بأن هذا العالم هو خير العوالم وإن وجد به بعض الشر ، وأن الخير سوف ينتصـر في آخر

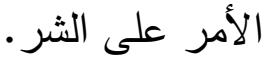


لمخــاطر تطــور المــرض الـذي يعـاني منـــه (Fontaine, 1994)، ويسـاعده على التغلب على

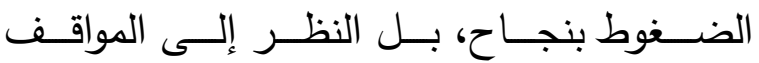

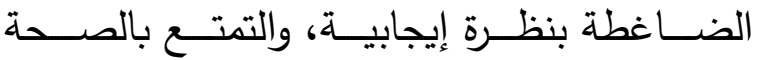
العضـويـة في مختلف المراحل العمريـة التي يمـر بها الأفراد سواء أكانوا بـالغين أم مـراهقين أم مـن

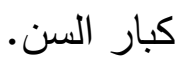

(Harju and Bolen, 1998 ; Kiyak, Vitaliano and Crinean, 1988 ; Chang, 2002)

وهو يعمل على تقليل تأثيرات المشقة على

الوظــائف الســيكولوجية مثـل إجــراء الفـــص

(Carver, et al., الهستولوجي للأورام الخبيثة (1993، أو التعـرض لجراحـة استئصـال سـرطان

الثدي في مراحل مبكرة. Scheier and Carver, (1992أو عند تعرضـهم لمشتقة إجراء جراحـات طبيـة خطيرة (كتحويـل مجرى الثـريان التاجي)، وهذا يجعلهم أكثر قدرة على الثـفاء السـريع مـع تعرضهم لمضاعفات صحية بسيطة بعد الجراحة، وذلك مقارنــة بـذويهم مرضـى القلب المتشـائمين، وهـذا يجعلهـم أسـرع فـي العـودة إلـى ممارســة أنشــتهم الطبيعيـة بعد إجـراء العمليـة الجراحيـة، مما يشير إلى أن التفاؤل يمكن أن يُنبئ بمحاولات التكيـف أو التغلـب على المشـكلات بعـد نتـائج الجراحة

(Scheier, et al., 1989 ; Scheier and

Carver, 1987) وهـا يؤكـد العلاقـة الإيجابيـة بـين التفـاؤل

وتحسن الحالة الصحية للمرضسى. Robbins) Spence, and Clark, 1991) الإيجابية بين التفاؤل وتحسن المزاج وارتفاع عدد

\section{تعريف الباحث للتوجه الإيجابي ذحو الحياة}

وممـا تقدم يصـوغ الباحث التعريـف التالي للتوجه الإيجابي نحو الحياة: "سمة في الثخصية توسم بأنها رؤية ذاتية إيجابية واستعداد كامن للى الفرد - غير محدود بشروط معينة - يُمكنه من توقع البشر ، وإدراك كل مـا هو إيجابي من أمور الحياة الجيدة وغير الجيدة، وذلك بالنسبة للحاضر الحالي والمستقبل القادم".

وبعـد هـذا التقــديم لتعريـف التفـاؤل لغويـا والتوجـه نحـو الحيـاة نتــاول هنـا علاقتـهـ بـبعض الســـمات النفســية والانفعاليـــة، والخصــــائص الشخصية والعضوية، وغيرها من المتغيرات، وذلك

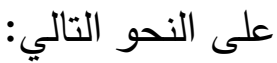

\section{التفاؤل والصحة العضوية والاثفمالية :}

تستحوذ دراسة التفاؤل على اهتمام بالغ من قبل الباحثين، نظرًا لارتباط تلك السمة بالصحة النفسـية والانفعاليـة والجسـدية للفـرد، فقـــ أكـدت دراسات متعددة على أن التفاؤل عامل رئيسي من عوامل العيش في صحة، والنجاح في الحياة، فهو يرتبط بأعلى درجات الهناء أو الرفاهية الانفعالية

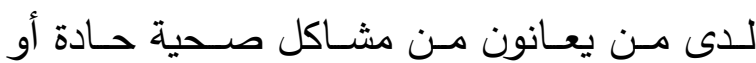
مزمنة، بل إنه يسهم-بالنسبة للمرضى -في جعلهم أكثـر احتمـالا وتركيـزًا مـن غيـرهم مـن غيـر المتفائلين على المشاكل التي يعانون منها بشكل يساعدهم على حل تلك المشاكل Gillinder and) Stephen, 2005) كما أنـه يسهم في مسـاعدتهم على التحكم النفسي في الانفعالات عندما يصـابون بالأمراض (Taylor, et al., 1992)، كما يسهم في إدراك الفرد 
ودراسـة (Smith, et al., 1989)، ودراسـتا (Hale, Marshall, et al., 1992, 1994)

Feidler, and Cochran, 1992)

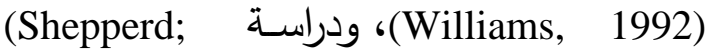

Boland ودراسة، Maroto, and Pbert, 1996)

and Coppliez, 1997) ودراسـة (عبد اللطيف

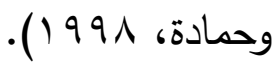

وبالنســبة للدراســات التـي تتاولــت بعـد

العُصابية، فقد تباينت النتائج ما بين وجود علاقة ارتباطية سالبة دالة مع التفاؤل - باعتباره سمة من سـمات الثخصية - ومـا بين عدم وجـود فروق إحصـائيًا، فمن الدراسـات التي أكدت على وجود علاقة ارتباطية سالبة دالة بين التفاؤل والعصـابية، دراسـة (Scheier and Carver, 1987)، ودراسـة (Williams, ودراسـة(Smith, et al., 1989) (1992)، ودراسـة (Brebner, et al., 1995)

ودراسـة (عبد اللطيف وحمـادة، 991 (1)، ودراسـة (Boland and Cappliez, 1997)، وهناك أيضًا دراستا (Marshall, et al., 1992, 1994)، أمـا الدراسـات التي أشـارت إلى عدم وجود علاقــة ارتباطيــة دالــة إحصــائيًا بــين التفــاؤل والعصـابية، فهي متعددة، ولعل من أهمها دراسـة .(Hale; Fiedler and Cochran, 1992) التفاؤل وعلاقتهله بـالقلق وقّلق الموت: نتــاول فيمـا يلـي علاقـة التفـاؤل بكل مـن القلق، وقلق المـوت، والاكتئساب، فبالنسـبة للقلق نجد أن دراسة (Dember, and Brooks 1989)، قد أشارت إلى أن التفاؤل يرتبط ارتباطًا سلبيًا دالاً مع القلق، وكذلك دراسة Treharne, Lyons, and العصبية القاتلة Natural Killer Cells، بما يعني زيــادة كفـاءة عمـل جهـاز المناعـة فـي الجسـم (Segerstrom, et al., 1998) وهذا يجعل للتفاؤل دورًا مهمًا في الارتقاء بحيـاة الإنسـان ورفاهيتـه مـن النـاحيتين النفسـية والبدنية، حيث تبين وجود ارتباط جوهري موجب بين التفـاؤل والصـحة الجسـية، وارتبـاط جوهري سـالب بـين التفـاؤل وكـل مـن التشــاؤم والثـكاوى الجسمية، كمـا كثف التحليل العـاملي عن وجود تجمعسين ارتبـاطيين يجمعهمـا عامـل واحد ثـائي القطب، الأول: يضم كل من التفاؤل والصحة، في حين يشتمل التجمع الثاني على كل من التشـاؤم والأعراض الجسمية. (أحمد عبد الخالق، 1991 19

\section{التفاؤل والأبعاد الأساسية للشخصية:}

أجريت دراسـات متعددة تتاولت التفاؤل في

علاقتـــه ببعــدين مــن أهــم الأبعــاد الأساسـية للشخصـية، وهمـا بُعدا الانبسـاط والعصـابية، وقد تباينـت عينـات الدراسـات مـا بـين طـلاب الثانوي والجامعـة مـن الجنسـين، ومـوظفين وموظفـات، ومسـنين ومسـنات، وغيـر ذلـك، كمـا اسـتُخدمت مقاييس متعددة لقياس التفاؤل في علاقته بهذين البعـدين، ولعـل مـن أهمهـا اختبـار التوجــه نحـو الحيـاة، واختبـار التوجـهـ نـــو الحيـاة المُعـدل، واستخبار أيزنك للشخصية. وقــــ بينـــ الدراســات أن التفــاؤل يـرتبط ارتباطًا جوهريًا موجبًا دالاً مع الانبساط، ومن هذه لَّاب الدراسات: دراسة (Funk and Houstom, 1987)؛ 


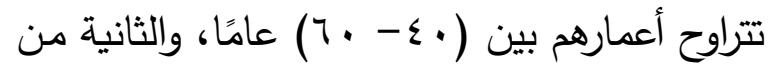
المسنين الذين تجاوزوا الستين من العمر.

\section{التفاؤل والأداء المهني أو الوظيفي:}

توصلت نتائج بعض الدراسات إلى وجود

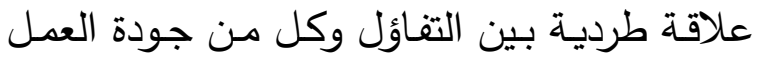
ومعـدل الإنتــاج، والانضـباط وحصــافة الــرأي والتوجيه، والأداء بشكل عام، كما تبين أن الذكور أكثر درايـة بالعمل، وهم أكثر مبادرة في طرح

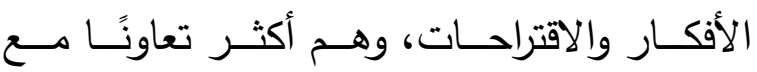

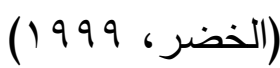

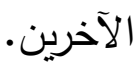
هذا ويرتبط التفاؤل إيجابيًا بكل من التحدي

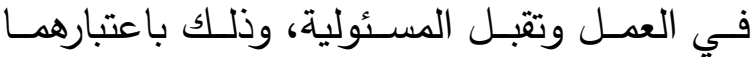
ميكـانيزمي دفــاع، كمــا ارتـبط التفــاؤل عكسـيًا بالهروب في مجال العمل. Hart and Hinter, 1995)

كمـا تبـين أن للعمـل نتـائج ايجابيـة على الثـــص، فقـي دراســة مقارنــة بـين العـاملين والطلاب تبين أن العمل يسهم في إحساس الفرد بالتفاؤل، فالعاملين أكثر تفاؤلا من الطلاب الذين لا يعملون (Lai, 1997)

كمــا تبـين فـي الدراســة ذاتهـا أن درجـات العاملون على مقياس التوجها نحو الحياة (LOT) ترتبط ايجابيًا مع الوجدانات الإيجابية وسلبيًا مـع الوجدانات السلبية، كذلك يـرتبط التفاؤل بالرضـا عن المهنة ارتباطًا إيجابيًا دالاً. Lounsbury, et al., 2004)

وفي دراسة مقارنة على عينة من الصينيات العاملات والمتعطلات عن العمل من هونج كونج،

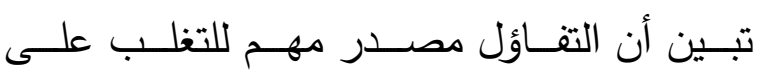
المشكلات الناجمة عن التعطل عن العهل، كمـا
التي أكدت على أن التفاؤل Tupling, 2001) يرتبط ارتباطًا جوهريًا سلبيًا دالاً مع التلق، وأخيرًا

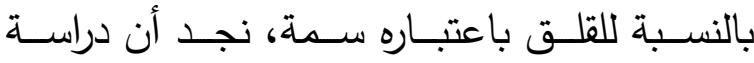
Scheier; Carve, Bridges, 1994

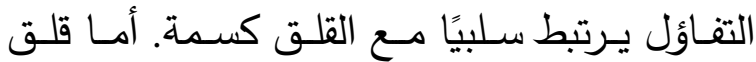

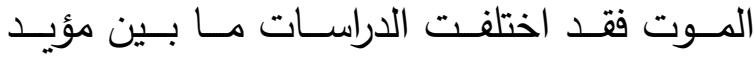
ومعسارض لوجود علاقـة ارتباطيـة من عدمـهـ مـع التفاؤل، فدراسة (أحمد عبد الخالق، 991 ("أ") أكدت على وجود علاقة ارتباطية سالبة دالة بين

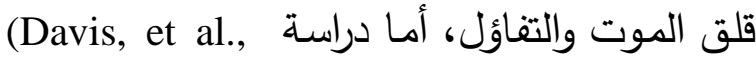
(1992، فقد كثفت عن عدم وجود ارتباط دال بين التفاؤل وقلق الموت.

\section{التفاؤل وعلاقته بـالتشاؤم:}

تتاولـت معظـم الدراسـات متغيـر أو ســة التشاؤم على الأخص في علاقته بالتفاؤل، وهل العلاقة بينهما سالبة دالة أم غير ذلك، خصوصًا وأن معظم نتائج الدراسات كثفت عن أن العلاقة بينهما هي علاقة ارتباطية سالبة دالة، من هذه الدراسات دراسة (Scheier and Carver, 1987)، ودراسة (Davis, et al, 1992)، ودراسة Dember) (عبد الخالق،

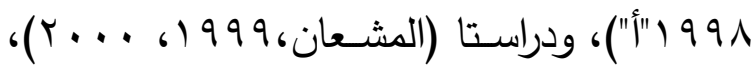

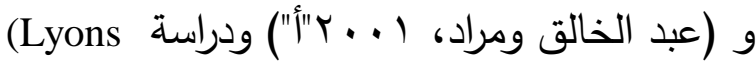
((Treharne, ودراسة \& Chamberlain, 1998) وكذلك في دراسة Lyons, and Tupling, 2001) (Scheier and Carver, 1985) (Plomin, et al., 1992)، فلم تكشف عن علاقة ارتباطية دالة بينهما، وذلك في دراستهم التي قاموا

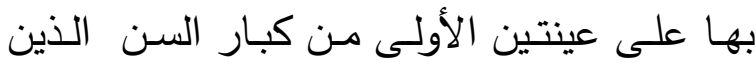


مسـتوى الإنجـاز الأكـاديمي بمعنى أن مرتفعي

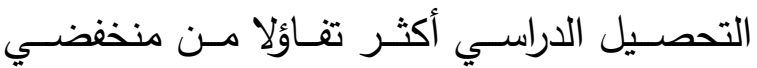
التحصيل الدراسي. (Malik, and Rehman, 2000)

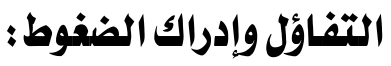

وفي مجال التعرف إلى العلاقة بين التفاؤل وإدراك الضـغوط للىى عينـة من طـلاب الجامعـة، مع افتراض أن المستويات العليا من التفاؤل ينبثق

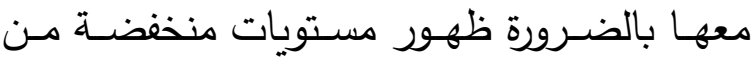
إدراك الضــغوط، تبـين وجـود ارتبـاط قـوى بـين التفاؤل وإدراك الضغوط، حيث كثفت النتائج عن أن الــدرجات العليـا مـن التفــاؤل تـرتبط ســلبيًا

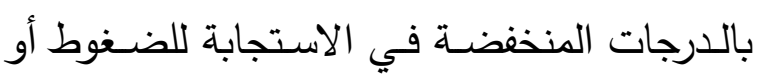
إدراكها

(Sitz and Poche, 2002)

كمـا كثـفت دراسـة Aspinwall and عـن وجـود علاقـة بـين إدراك الضـغوط والتفـاؤل لدى طـلاب الجامعـة، فالذين يحصـلون علـى درجـات مرتفعـة فـي التفـاؤل يحصلون في الوقت ذاته على درجات منخفضــة في إدراك الضغوط في في لمون

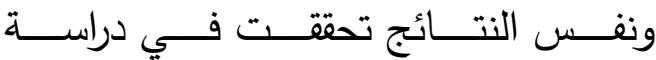
(Segerstrom, et al., 1998)، كما وجد أن هناك دراك علاقة بين التفاؤل والاستجابة للضغوط لدى عينة من طـلاب الجامعة، فالأشخاص الذين يتكيفون

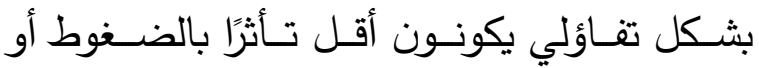
المواقف الضـاغطة، بـل يرتفع مسـتوى الإنجـاز الأكاديمي لديهم.(Malik and Rehman, 2000)، والتفـاؤل يسهم أيضًا بشكل فعـال في أنـهـ يقود
أن التعطل عن العمل يؤثر على الصحة النفسية،

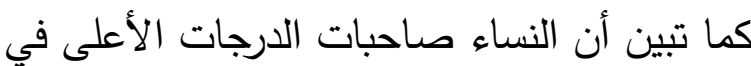
التفاؤل هن اللاتي كن قادرات على إبعاد أنفسهن

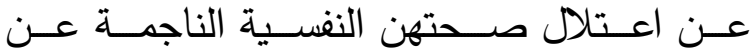
الإخفاقات في العمل. (and Wong, 1998

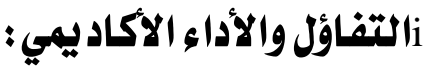

توصـلت نتـائج بعـض الدراسـات إلـى أن

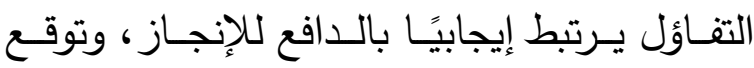

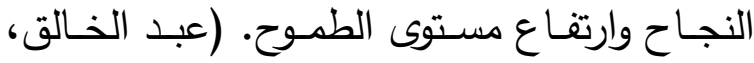

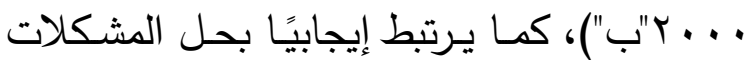

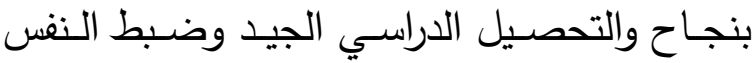

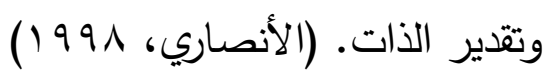
كمـا تبين أن المـراهقين الذين يعـانون مـن مشاكل الاستذكار يعبرون في رسومهم وكتاباتهم عن موضوعات يغلب عليها جو التثاؤم أكثر من التفاؤل. (عبد العزيز ، 911 (1) كما تبين أن الطريقة التي يفسر بها الفرد الأحـداث سـواء أكانت تفاؤليـة أم تثــاؤمية تـؤثر

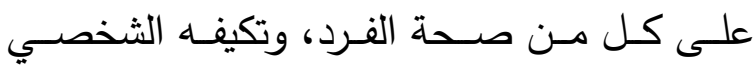

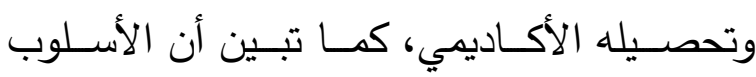
التفسيري التفاؤلي يختلف بتقدم الفرد في مراحل

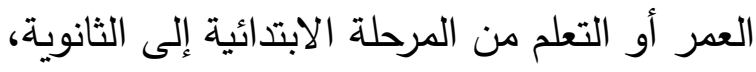
بل من التعليم غير المختلط (ذكور أو إناث فقط) إلى التعليم المختلط (ذكور وإناث). وأكدت الدراسة على وجود علاقة ارتباطية موجبة بين التفاؤل والإنجاز الأكاديمي. (Yates,

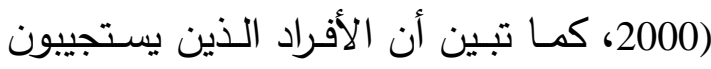

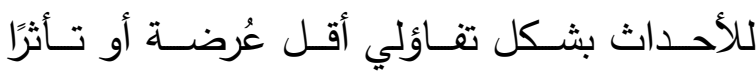
بالضغوط أو المواقف الضاغطة، كما يرتفع لديهم 
لمرضى الثريان التاجي الذين أجريت جراحة لهم تُعرف جراحيًا باسم "تطعيم النسيج الحي للشريان

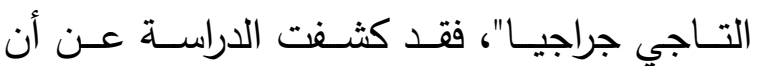
التفــاؤل والتثــاؤم مكونــان منفصــلان لا يمكـن الاعتمـاد عليهمـا بشكل متسـاو يمكن معـه التتبؤ بأن أحدهما يُسهرم في التنبؤ بالقدرة على الثفاء النغسي والبدني. (Mahler and Kulik, 2000)

وفي دراسة تتبعية أخرى مدتها (0) سنوات على عينة من المرضـى ممن أُجريت لهم جراحة Coronary المجـرى الجـانبي للثـريان التـاجي artery bypass surgery كونـه مُنبئًَ بالثـعور الذاتي بالصـحة، وبـأن كل شـيء على مـا يـرام للدى هؤلاء المرضـى، فكان المتفـائلون -على العكس مـن المتشــائمين - أكثر احتمالا أن يقرروا شعورهم بالراحة بعد النوم، وأقل

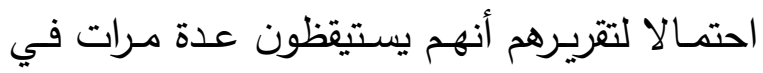
نهايــة فتـرة نــومهر، وقـرر المتفـائلون أيضًَــا أن حيـاتهم مسـلية وشـائقة ومتحـررة مـن الضـــوط

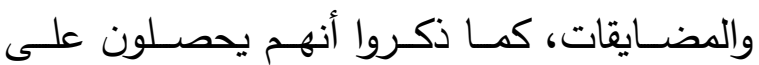
إشباع ورضـا كبيرين نتيجة علاقاتهم بأصدقائهح فضلا عن الإشباع والرضا عن العمل. (Scheier and Carver, 1992)

ونضـيف لمـا سبق مـا أكدته دراسـة أجريت

تبـين منهــا أن المتفــائلين يتعرضــون لانخفــاض

ضغط الدم الانقباضي Systolic blood pressure (SBP)، كمــا أظهـرت الدراسـة أن معـدل نـبض . القلب ينخفض بمرور الزمن لدى المتفائلين، كما تثـير الدراســة إلـى بقــاء الإنســان وتحـرره مـن

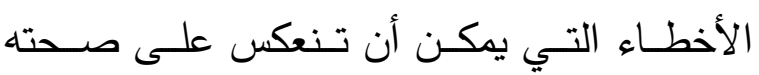

الشخص إلى التغلب على الضغوط والتكيف معها على نحو ملأئم. (Scheier and Carver, 1992)

\section{التفاؤل بـاعتبـاره منبئًا ببعض المتفهرات :}

لا تقتصـر العلاقـة بـين التفـاؤل وغيـره مـن المتغيرات السابق ذكرها على مجرد وجود أو عدم

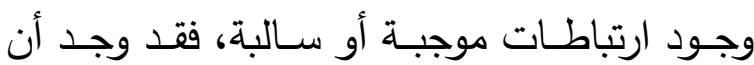
التفـاؤل الـذي تم تقديره لعدة أسـابيع ظلـل مُنبئًا جوهريًا لفترة تجـاوزت ثلاثـة أسـابيع بعـد مـرور الولادة.(Carver, and Gaines, 1987) كذلك تبين في دراسـة كان هدفها بحث مـا إذا كـان التفــاؤل يُنبـئ بحـدوث تغيـرات صــية مرتبطة بخطر حدوث مرض القلب لدى عينة من مرضسى القلب المشتركين في برنـامج تأهيلي، أن التفاؤل يرتبط بالنجاح الكبير في تحقيق مستويات منخفضـة في كل مـن الـدهون المشبعة ودهـون الجسم وخطر الوقوع في الأزمة القلبية. كما ارتبط التفاؤل بالنجاح الكبير في زيادة تحمل التمرينات الرياضية في نهاية البرنامج. (Shepperd, Maroto, and Pbert, 1996) وفي هذا الصـدد نـكر أنـه حين فحصـ العلاقـة بين التفـاؤل والتشــاؤم وكل مـن الرياضــة والنشـاط الجسـمي والصــحة الجسـمية، تبـين أن الأفراد الذين يتمتعـون بدرجـة عاليـة مـن النشـاط كـانوا أكثـر تفــاؤلا، وأن المتفـائلين كـانوا أكثـر التصاقًا بالرياضة وممارسة التمرينات الرياضية. (Kavussann, and Auley, 1995) وعلى العكس مـن ذلـك في دراسـة كـان الغرض منها التعرف إلى فائدة كل مـن التفاؤل والتشاؤم (على المدى البعيد)، وبمعنى آخر القدرة التتبؤيسة لهما على إحداث الثفاء البدني والنفسي 
الأشياء الجيدة أو الإيجابية لكل ما هو مستقبلي".

-(Scheier and Carver, 1987)

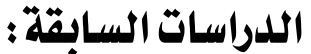

نـادرة هـي الدراسـات الســابقة-العربيـة أو

الأجنبيـة-التـي تناولـت اتجاهـات الفـروق بـين

الجنسين على بنود اختبار التوجـه الإيجابي نحو

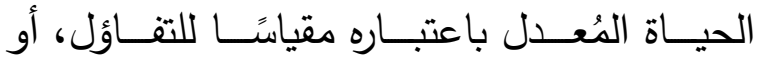

باستخدام مقاييس أخرى تقيس التفاؤل على وجـه الخصوص، مع متغيرات أخرى.

وينـوه الباحـث إلى أن هـه الدراسـات كـان

يمكن تصـنيفها إلى دراسـات اسـتخدمت اختبـار التوجهـ نحو الحياة باعتباره مقياسًا للتفاؤل، وهي دراسـات أجنبيـة في الغالـب باسـتثناء الدراسـات العربيـة التـي عربــت الاختبـار واسـتخدمته على عينـات عربيـة، أو التـي أعـدت أداة تمثل قائمــة التوجـه إزاء الحيـاة، وهنـاك دراسـات عربيـة أعدت مقياسًا للتفاؤل استخدمته على عينات عربية، وقد فضـل الباحث عرضـها معـا كونها تقيس التفاؤل

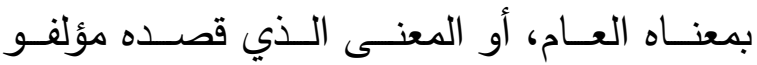
الاختبار الأصليين

وعليه وفي ضوء ما استطاع الباحث جمعه

مسن دراسـات سـابقة عربيـة وأجنبيـة متعلقـة بهـذا الموضوع، يعرض الباحث ما يلي:

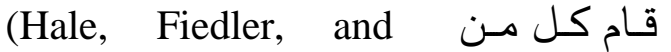

Cochran, 1992) بتطبيق المقياس المعدل للتوقع العـام للنجـاح باعتبـاره مقياسَـا للتفـاؤل، ومقيـاس تقدير الذات، واختبار التوجه نحو الحياة، ومقياس وجهة الضبط الداخلي/ الخارجي، وذلك على عينة قوامهـا (99 (19) مـن طـلاب الجامعـة، وقد كثفت
(Scheier and Carver, 1985)

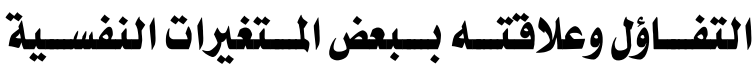

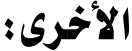

وأخيـرًا نعـرض لنتـائج عـد مـن الدراسـات

التي تتاولـت علاقـة التفــاؤل بـبعض المتغيـرات النفسية الأخرى التي لم يرد ذكرها أنفًا، فقد تبين ارتباطه سلبًا مـع كل من اليأس ئس (Scheier and) (Fischer and Lietenberg, ،Carver, 1987) (Hale, Feidler and (1989) ومصدر الضبط Cochran,

والجسـية (المشـعان، . . . ب)، في حين ارتبط إيجابًا مع الثعور بالسعادة والصحة النفسية (عبديد الخـالق ومـراد، ا . . . "أ")، ومـع الرضـا الوظيفي (المشعان، Y . . . Y)، ونمط السلوك "أ" (أحمد عبد

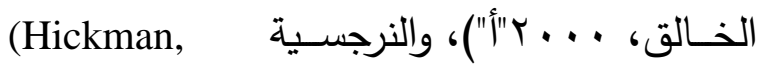
Watson, and Morris, 1996) .(Marshall and Lang, 1990)

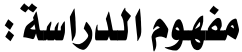

عرف كل من (Scheier and Carver, عن (1985 التوجها الإيجابي نحو الحياة بأنه: "النظرة الإيجابية، والإقبال على الحياة، والاعتقاد بإمكانية تحقيق الرغبات في المستقبل، وأن تلك الرغبات سوف تتحقق وتُشـبع في النهايـة، بالإضـافة إلى الاعتقاد باحتمـال حدوث الخير أو الجانب الجيد مـن الأشـياء بـدلا مـن حـدوث الثـر أو الجانـب السيى"،(Scheier and Carver, 1985) كمـا عُرف أيضًـــا فـي موقــع آخـر بأنــه "اسـتعداد عـام يكمُنـ داخـل الفـرد لتوقـع حـدوث 
العمــر ، وممــتوى التعلـيم، والحالـــة الزواجيـــة

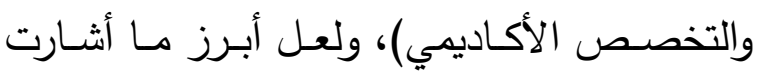
نتائج الدراسـة إليهه هو عدم وجود فروق جوهريـة بين الذكور والإنـاث في التوجـه إزاء الحياة، كمـا كثفت النتائج عن ارتباط موجب ودال بين التوجه الإيجابي نحو الحياة "التفاؤل" وكل من الاعتداد

بالذات، والحالات المزاجية اليومية الإيجابية.

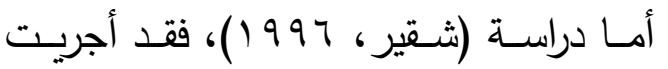

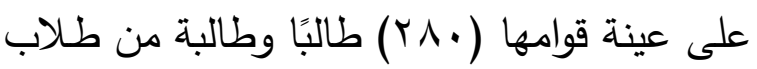
الجامعـة، وقد طبقت عليهم ثلاثـة مقـاييس هي التعصب، والاكتئاب والسيكوسوماتيك، وقد اعتبرت

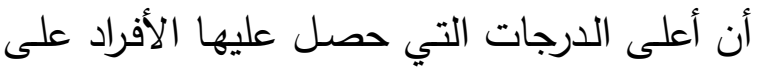

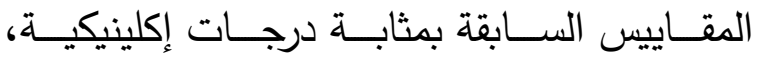
ولتحقيق هذا اختارت أعلى (ب0) درجـة للأفراد على المقاييس الثثلاثة من الجنسين، والباقي من

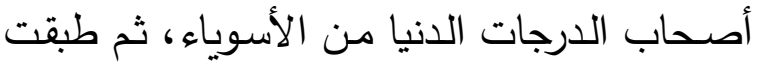
(r) مقاييس أخرى هي الطمانينة والتفاؤل والتشاؤم وقلق الموت. وقد بينت النتائج وجود فروق دالة لصالح الأسوياء على مقياس الطمأنينة والتفاؤل. كما بينت النتائج وجود علاقة ارتباطية دالة بين الطمأنينة النفسية والتفائل، ووجود علاقة ارتباطية سالبة دالة بين قلق الموت والتفاؤل، وكذلك بين التفاؤل والتثــاؤم، كما بينت النتائج وجود فروق لئن دالة بين الجنسين في التفاؤل لصالح الذكور . ودرس (Chang, 1996) الفروق الثقافية بين طلاب الجامعة الأمريكان ذوي الأصول البيضـاء

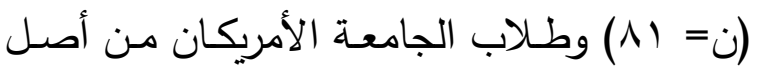
آسـيوي (ن= (^)، وذلــك فـي درجــة التفــاؤل والتشـاؤم والمشقة ومـدى ارتبـاط ذلك بالمشـاعر
النتائج أن اختبار التوجه نحو الحياة يرتبط إيجابيًا

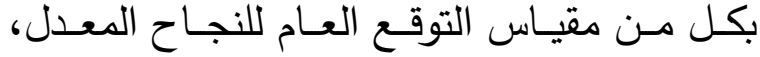
وكذلك تقدير الذات، كما ارتبط إيجابًا بالانبساط، وسلبًا بالعصابية.

كما قام كل من Mook, Kleijin and (Ploeg, 1992)، بدراسة على عينة قوامها (77 ) من طـلاب الجامعـة وأخرى من الراشدين قوامهـا (Y (r )، وقد تراوح المدى العمري لهم بين 19 19

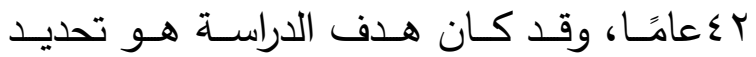
الدكونات العاملية لمقياس التوجه نحو الحياة، وقد

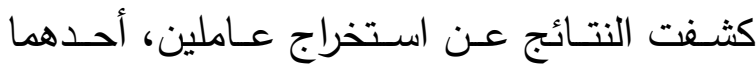
لالتفاؤل والآخر للتثاؤم.

وقـام (هريدي، ـ99 (1)، بدراسـة استهدفت

التعرف إلى طبيعة العلاقة بين التوجه إزاء الحياة (التفاؤل/ التشاؤم) وبين كل من الاعتداد بالذات، والحالات المزاجية - الإيجابية والسلبية- اليومية،

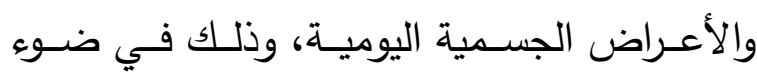
النوع، والعمر ، ومستوى التعليم، والحالة الزواجية

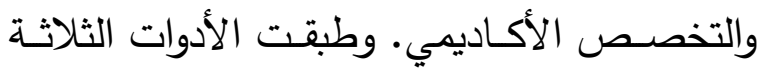

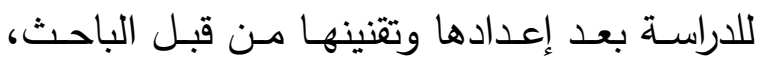

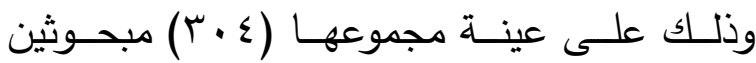
يثـتملون على الخصــائص المستهدفة بالبحـث، وذلك بطريقة فردية وجمعية، والأدوات هي: قائمة التوجها إزاء الحياة، ومقياس الاعتداد بالذات، ثم

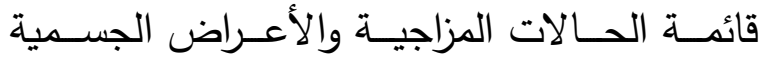
اليوميـة. وأسفرت الدراسـة عن وجـود فروق بـين

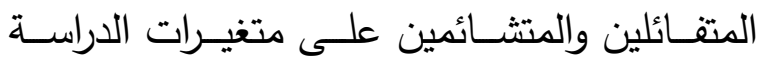
الأخرى، كذلك وجود فروق بين مختلف العينات الفرعية في ضوء الخصائص المشار إليها (النوع، 
الحياة على عينة من طلاب الجامعة من الجنسين قوامها (ع اب)، كما طُبق الاختبار ذاته على عينة

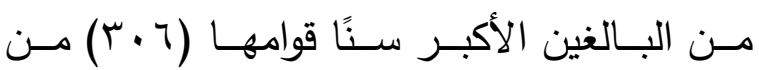

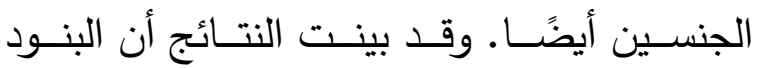
الإيجابيـة تمثـل التفــاؤل والبنــود السـلبية تمثـل التشـاؤم، وذلك لدى عينتي الدراسـة، كمـا كثفت

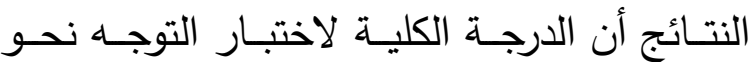
الحياة الصـيني هي أفضل sُنبـئ بالمقاييس التي تقيس سـمات الشخصـية أو الأعـراض الجسمية، وقد أشار الباحثان إلى أننا في حاجة إلى مزيد من البحـوث لقيـاس التفــاؤل لـدى الثــب الصـيني، وكذلك لتوضيح العلاقة بين التفاؤل والتشاؤم. (Robinson-Whelen., 1997) وقامـت بتطبيق عدة مقـاييس هـي: اختبـار التوجـه نحـو الحيـاة، ومقيـاس ضـغوط أحـداث الحيـاة السـلبية، ومقيــاس الاكتئـاب، ومقيــاس إدرالك الضـــوط، ومقيـاس القلـق كحالـة، وأخيـرًا مقيـاس الوجـــان الإيجابي السلبي، وذلك على عينتين الأولى من متوسـطي العمـر ، والثانيـة مـن كبـار السـن، وقد كثف التحليل العـاملي التوكيدي لمقيـاس التوجـه نحو الحياة عن عـاملين منفصلين همـا: التفاؤل والتثـاؤم، وذلك لـدى كل عينـة على حدة. كمـا كثـفت الدراسـة أن ضــوط أحسداث الحيـاة تـؤثر على الأفراد موضـوع الدراسـة، فالذين يتعرضـون لضـغوط أحداث حياتيـة أقل يكونـون أكثر تفـاؤلا والعكس صـحيح. وقد كثفت الدراسـة أن التفـاؤل لـدى الأفراد البـالغين الذين يعـانون الضــوط قد ارتبط بقوة بالوجدان السلبي والقلق والاكتئاب. ومن النتائج الجديرة بالاهتمام أن التثاؤم وليس التفاؤل
الإيجابيـة والسـلبية، وكـذلك التوجـهـ السـلبي أو

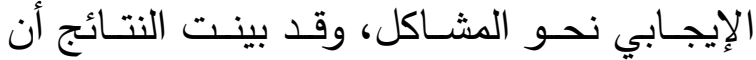
التفاؤل يرتبط ايجابيًا- ارتباطًا مرتفعًا- بالمشاعر الإيجابية والتوجـه الإيجابي نحو حل المشكلات. وقد انطبقت هذه النتيجة على كل أفراد العينـة من الأصـلين المختلفين (ذوي الأصـل الأبـيض وذوي الأصل الآسيوي) من الأمريكيين. وقامـت (Lai, 1997)، بتطبيـق النسـخة الصـينية لمقيـاس التوجـهـ نحــو الحيـاة باعتبـاره مقياسًا للتفاؤل وقائمة الأعراض الجسمية ومقياس الوجدان الصيني، وذلك على عينـة قوامها (. بr) مـن طـلاب الجامعـة، و( I ) مسن المـوظفين العاملين، وقد كثفت النتائج العاملية عن عاملين أحدهما عامل للتفاؤل والآخر للتشاؤم، وذلك لدى كل من العينتين، ولكن هذين العاملين لم يـتبط أيُّ منهمــا بقائمــة الأعـراض الجسـمية أو مقيـاس الوجدان الصـيني. وبينــت النتائج أيضًا أن القوة التنبؤيسـة لمقيـاس التوجـهـ نـــو الحيـاة عمومًا يـتم بحثها باعتبارهـا مقياسًا للتفـاؤل أكثر مـن كونها مؤشـرًا للتشــاؤم، كمــا أشــارت النتــائج إلــى أن أن المكونين "التفاؤل والتشـاؤم" يقيسـان نفس المكون لاى العينتين "التفاؤل" ولكن البنود الإيجابية تقيس التفاؤل على نحو أفضل، ولذلك يجب النظر في الاختبار باعتباره اختبارًا يقيس التفـاؤل والتشـاؤم باعتباره مفهوم ثنائي القطب. وفي دراسـة كـان هدفها الأساسـي الإجابـة عن السؤال: مـا الذي يقيسـه اختبار التوجه نحو الحياة؟ قام (Cheng and Hamid, 1997) بتطبيق النسـة الصينية من مقياس التوجهاه نحو 
الثخصـية الفصـامية وكل مـن التفـاؤل والتشـاؤم، وذلك على عينة من طلاب كلية التربية الأساسية بالهيئــة العامــة للتعلـيم التطبيقــي وكليـة الآداب

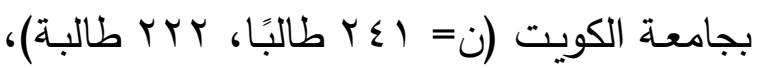
وقـد كثـفت النتـائج عـن وجـود فـروق دالـة بـين الجنسين في التفاؤل لصـالح الذكور ، في حين لم تكن الفروق دالـة بينهمـا في التشـاؤم، كمـا بينـت النتـائج وجـود علاقـة ارتباطيـه سـالبة دالـة بـين التفاؤل والتشاؤم لدى كل من الإناث والذكور ، كما اتضـــح أن الارتبــاط بـين التفــاؤل والثخصـية الفصسامية لدى عينتي الذكور والإناث كان سـالبًا

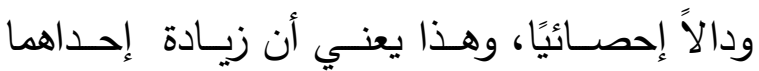
تـنقص الأخـرى، كمـا أن الارتبـاط موجـب بـين التشاؤم والثخصية الفصامية لدى الجنسين. أما دراسة (شكري، 999 ())، فقد هدفت إلى إعـداد مقيـاس لتقـدير الأسـاليب العامـة لمواجهــة المشقة لله من الخصـائص السيكومترية مـا يجعلـه أداة سيكولوجية ملائمة للاستخدام في هذا المجال. هذا من جانب، ومن الجانب الآخر هدفت الدراسة إلى الكثف عن الفروق بين الجنسين في متغيري التفـاؤل والتشـاؤم، فضـلا عـن الفروق بينهمـا في استخدام أساليب مواجهة المشقة، مع تبين طبيعة علاقـات الارتبـاط بـين كل مـن التفـاؤل والتثـاؤم

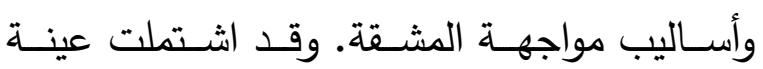
الدراسة على (0) طالبًا ،0 r ا طالبة) من طلاب الجامعـة، وتـم تطبيـق مقيـاس أسـاليب مواجهـة المشقة (من إعداد الباحثة) والقائمة العربية للتفاؤل والتشـاؤم مـن إعداد أحمد عبد الخـالق (799 ( ) )، وقد أشارت نتائج التحليل العاملي إلى أن مقياس
كان منبئًا بالصـحة النفسية والعضـوية وإنهمـا التفاؤل والتشـاؤم- تسـاويا باعتبارهما من العوامل

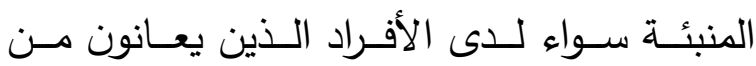
الضغوط أو الذين لا يعانون منها. ودرس (عبــد اللطيــف وحمــادة، 991 ( ) علاقـة التفــاؤل ببعـدين مـن الأبعـاد الأساسـية للشخصية وهمـا: بُعدا الانبسـاط والانطواء، وذلك

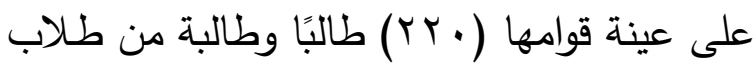
جامعة الكويت. وقد بينت النتائج أن التفاؤل يرتبط ايجابيًا بالانبساط، كما يرتبط سلبيًا بالعصابية. وفـي دراســة عامليـة قـام (عبـد الخـالق،

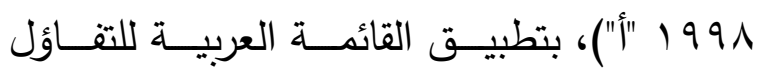
والتشـاؤم ومقيـاس قلق الموت، وذلك على عينـة

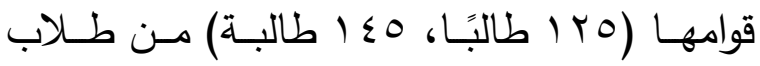
جامعـة الكويــ، وقـد اسـتخرجت ارتباطـات دالـة إحصـائيًا بين التفاؤل والتشـاؤم (سلبية)، والتفاؤل وقــق المـوت (سـلبية)، والتشــاؤم وقــق المـوت (إيجابية)، وتتطبق هذه الارتباطات على الجنسين كل على حدة، ممـا يعطي التدعيم لهذه النتائج، واسـتخرج مسن معساملات الارتبـاط عامـل ثــائي القطب للتفاؤل مقابل التشاؤم (تتراكم الأدلة على

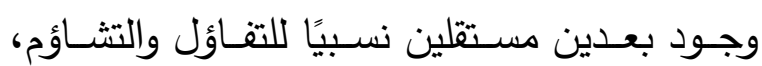

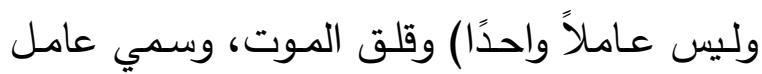
الاستبشار - الضيق، كما بينت النتائج عدم وجود فروق دالة بين الجنسين في التفاؤل والتشاؤم، في كانت الفروق دالة بينهما في قلق الموت لصـالح الإناث. وفـي دراسـة لكل مـن (العنـزي والمشـعان، 199 ( )، والتـي كـان هـدفها دراسـة العلاقـة بـين 
النفسية الجسـمية، حيـث إن الـكور كـانوا أكثر

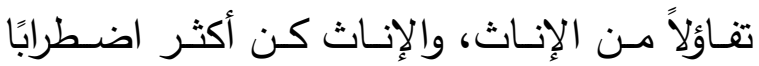
نفسيًا جسميًا من الذكور ، وكذلك لا توجد فروق جوهرية بين الذكور والإناث في التشاؤم وضغوط الحياة، وكثفت النتائج عن وجود ارتباط جوهري سلبي بين التفاؤل والتشاؤم، ولكن لا يوجد ارتباط سلبي جوهري بين التفاؤل والاضطرابات النفسية والجسمية وضغوط أحداث الحياة، وكذلك لا يوجد ارتباط موجب جوهري بين التشاؤم والاضطرابات النفسية الجسمية وضغوط أحداث الحياة. وقد قامت كل من Malik, and Rehman) (2000، بدراسـة هدفت إلى التعـرف إلىى العلاقـة بين التفاؤل والتشـاؤم وقابليـة الاستجابة للضـغوط والإنجاز الأكاديمي، وذلك لدى عينـة من طلاب الجامعة الباكستانيين بواقع ( .0 من الذكور ، . . من الإنـاث)، وهـم في المدى العمـري من (v) 9 (1) عامًا، وقد افترضـت الدراسـة ثمانيـة فروض هـي: (1) توجـد علاقـة ارتباطيــة بـين التفـاؤل والتشـاؤم وقابلية الاستجابة للضـغوط (Y) التفاؤل يرتبط عكسيًا مـع قابلية الاستجابة للضـغوط (ب) الإنـاث أكثر تفاؤلا (ع) الذكور أكثر استجابة أو تـأثرًا بالضـغوط (0) مرتفعـو التحصـيل الدراسـي أكثر تفـاؤلا (7) مرتفعـو التحصـيل أقـل اسـتجابة للضغوط (V) الطلاب الذين ينتمون لحالات ذات مسـتوى اجتمــاعي - اقتصــادي مــنخفض أكثـر عُرضة للاستجابة للضغوط (^) أصحاب المستوى أل الاجتمـاعي الاقتصـادي المرتفع أكثر تفاؤلا. وقد طبق على أفراد العينة اختبار التوجه نحو الحياة، ومقيــاس قابليـة الاسـتجابة للضــوط، وبالنســبة
الأسـاليب العامـة لمواجهـة المشـقة يتضـمن ثلاثـة عوامل (مكونـات) هي: عامل التجنب (الإنكار ، عدم الانشـال السـلوكي، عدم الانشـال الذهني، كبح المواجهـة)، وعامـل التركيـز على المشـكلة

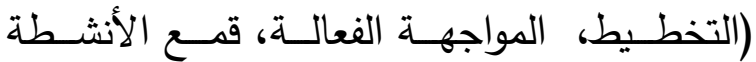
المتعارضـة، إعادة التقسير الإيجابي، البحث عن الـدعم الوسـيلي، التقبـل)، وعامـل التركيـز على الـى الانفعال (اللجوء إلى الدين، التركيز على الانفعال وتصريفه، البحث عن الدعم الانفعالي). كما بين اختبار "ت" وجود فروق دالة إحصـائيًا بين الذكور وبـين الإنـاث فـي التفــاؤل (لصــالح الــكور)، والتشـاؤم (لصـالح الإنـاث) وعـدد مـن الأسـاليب

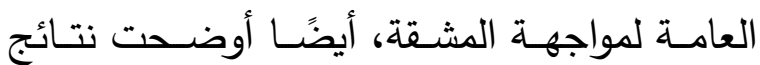
معاملات الارتباط الخطي أن هنالك علاقة ارتباط إيجابي موجب بين التفاؤل وبين أساليب المواجهة التي تركـز على المشـكلة، وبـين التشـاؤم وبـين

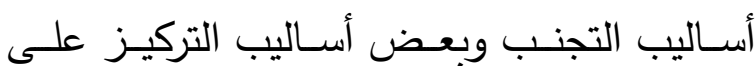

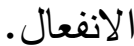

وقد هدفت دراسة (المشعان، . . . .)، إلى بحث العلاقة بين التفاؤل والتشاؤم والاضطرابات الجسـمية وضــوط أحـداث الحيـاة لـدى طـلاب الجامعة، وتكونت عينة الدراسـة من ( • ا (1) من الذكور و(09 1) مـن الإنـاث، وطبق على العينـة أدوات تشمل: مقياس التفاؤل والتشاؤم: إعداد عبد الخالق (799 (199)، ومقياس الاضطرابات الجسمية: إعداد (Gomes Vierra, 1994)، ومقياس ضغوط أحداث الحياة: إعداد (Holms \& Rahe: 1967)، وكشفت نتائج الدراســة عن وجـود فروق جوهريـة بـين الـذكور والإنـاث في التفـاؤل والاضـطرابات 
الجسمية، ومقياس اليأس الصيني ومقياس وجهة الضـبط الصـيني، وقد كثـنت النتائج عن تمتع جميع مقاييس الدراسة بخواص سيكومترية مقبولة. كما كثفت نتائج التحليل العاملي عن عامل واحد بالنسبة لعينة هونج كونج، وبالنسبة للعينة الصينية فقـد كشـت نتـائج التحليـل العـاملي عـن عـاملين أحداهما مرتبط بالبنود الإيجابية "التفاؤل"، والآخر يرتبط بالبنود السلبية "التشاؤم". كما كثفت النتائج

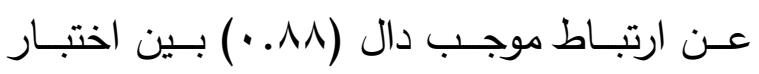
التوجــه نحــو الحيـاة "الصـيني" المُعـدل واختبـار التوجـهـ نحـو الحيـاة المُعـدل، كمــا ارتبط اختبـار التوجه نحو الحياة الصيني المُعدل بمقياس اليأس

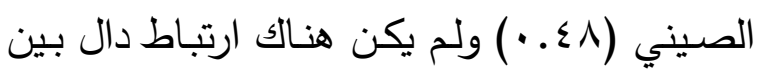
اختبار التوجه نحو الحياة الصيني "المعدل" وكل لهل مـن قائسـة الأعـراض الجسـيمة ومقيـاس الصـحة العام. وقد بينت النتائج اختبار التوجه نحو الحياة الصيني "المعدل" يرتبط إيجابيًا مع مقياس التفاؤل

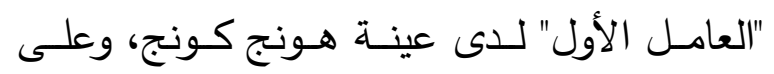

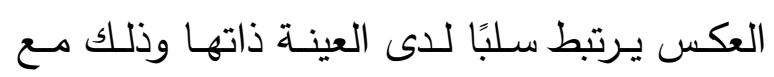
مقيـاس التثـاؤم "العامـل الثاني". والنتيجـة بثـكل عام بينت أن اختبار التوجه نحو الحياة الصيني

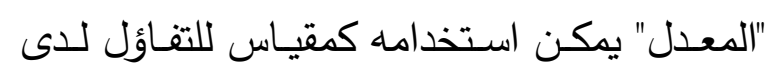
عينة هونج كونج، وعلى العكس من ذلك بالنسبة

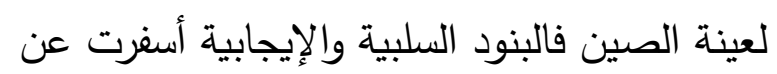
وجود عاملين هما التفاؤل والتشاؤم.

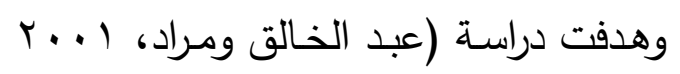

"ب")، إلى فحص ارتباطات التقدير الذاتي للصحة

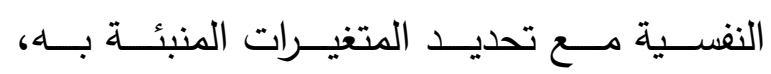
واسـتخدمت عينـة مـن الطلبـة والطالبـات بجامعـة
لقياس التحصيل الدراسي فقد تم الاعتمـاد على درجات الأفراد في آخر عام دراسي كانوا فيه، وتم تقسيم الدرجات إلى مرتفعة ومتوسطة ومنخفضـة، وقد تحققت جميع الفروض التي سعت الدراسة إلى التحقق منها، غير أن الفرضين الثالث والرابع قد تحققـا بشكل جزئي Partially، حيـ تبـين عدم وجـود فروق بـين الجنسين في كل مـن التشـاؤم وقابلية الاستجابة للضـغوط، غير أن الإنـاث كن لن فئن أكثر تفاؤلا من الذكور، والدراسة على النحو الذي الذي

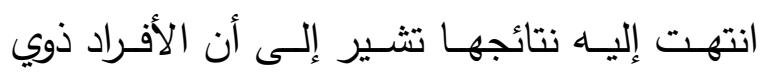
النمط التفاؤلي في اتجاهاتهم يكونون أقل عُرضــة للتــأثز بالضــغوط، وهــم متفوقـون فـي الإنجــاز الأكاديمي أو التحصيل الدراسي مقارنة بينهم وبين

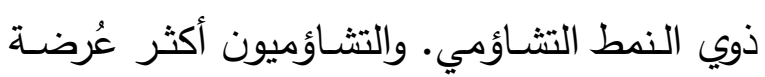
للقلق والتوتر الزائدين. وقد أشـارت الباحثتان إلى أن هذا ليس ما يحدث للأفراد، ولكن الطريقة التي يـرون المواقف بهـا ويفسـرونها هـي التي تُحِدث

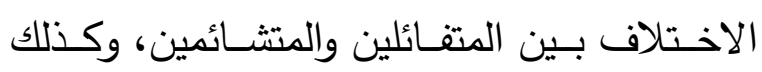
أشـارت إلى أن الإيجابية أو التفاؤل ليسا هما مـا يجعـلان الفرد أقل عُرضـة للضـوط فقط، ولكنهما أيضًا مفيدان بالنسبة لصحة الفرد بشكل عام. وقام كل من (Lai and Yue, 2000) بدراسة

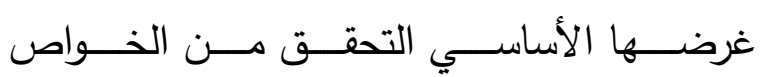
السيكومترية للنسخة الصينية لاختبار التوجـه نحو الحياة المُعدل، وذلك على عينـة من هونج كونج (ن= qr و ذكرًا، 17 ( أنثى)، وعينة أخرى صينية

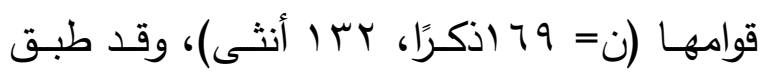
على أفراد العينتين مجموعـة أخرى من المقاييس

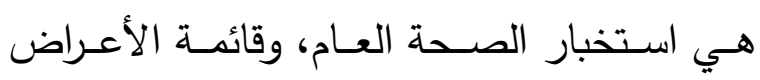


الدراسة عن تحقق جزء من الفرض الأول، حيث ظهرت الفروق الدالة بين الذكور والإناث في الثقة بالنفس فقط - للذكور متوسط أعلى - في حين لم تظهر فروق جوهريـة بين الجنسين فيمـا يتعلق فئق

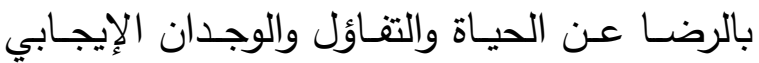
والسلبي. أما الفرض الثاني فقد تحقق بشكل تام، إذ تثير النتائج إلى ارتباط إيجابي بين الرضا عن الحياة والثقة بالنفس والتفاؤل والوجدان الإيجابي مـن جهـة وعلاقــة ارتباطيـة سـالبة مـع الوجـــان السلبي. وكثف التركيب العاملي عن عامل قطبي

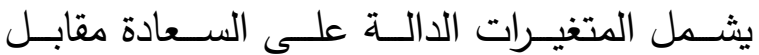
التعاسـة، وبينــت النتـائج أن التفــاؤل والوجــان التهان الإيجـابي والسـلبي متغيـرات منبئـة بالرضـا عـن

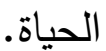

وقد هدفت دراسة (إسماعيل، ( +. †)، إلى التعرف إلى مقدار واتجـاه العلاقـة بـين التفـاؤل والتشاؤم وكل من الثعور بالوحدة النفسية، وقلق المـوت، ووجهــة الضـبط، والوضــع الاجتمــاعي الاقتصادي، كما هدفت إلى الكثف عن الفروق

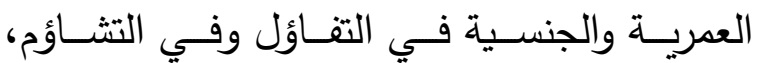
والتفاعل بينهــا، والتعـرف إلىى أكثر المتغيـرات

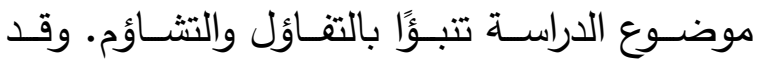

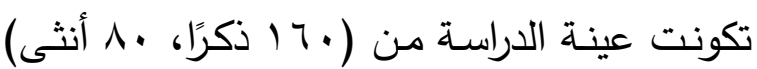
من طلاب جامعة أم القرى الذين تراوحت أعمارهم

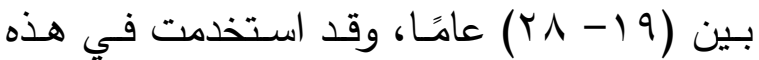
الدراسـة القائمسة العربيـة للتفاؤل والتثـاؤم، والقائمـة العربيـة لقـلق المـوت ومقيـاس الثـعور بالوحـدة النفسية ومقياس وجهـة الضبط. وأسفرت النتائج عن وجود علاقة ارتباطية سالبة دالة إحصائيًا بين
الكويــت (ن= 99 (1). وكثــفت الدراســة عـن معاملات ارتباط دالة إحصائيًا بين التقدير الذاتي

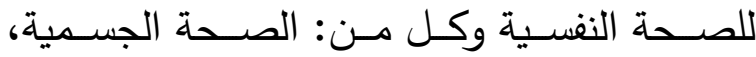
والثـعور بالسـعادة، ودافعيـة الإنجـاز ، والتفــاؤل،

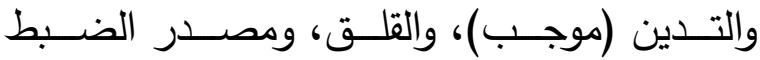

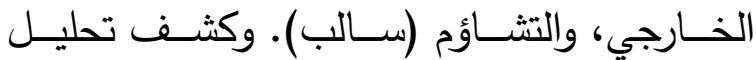

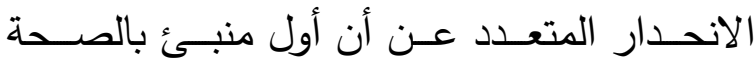
النفسية هو الشعور بالسعادة، حيث تتبأ بتباين قدره (90 . 0\%) في الصـحة النفسية، ثم كان لمتغير القلق الإسهام الثاني في الصحة النفسية

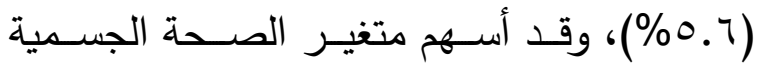
بمقدار (r\% )، من التباين المتنبأ به في الصحة النفسية، في حين أن متغيرات التفاؤل والتثـاؤم ومصدر الضـبط كـان تأثيرهم على التباين في الصحة النفسية ضئيلا، كما أن مستوى التدين لـ

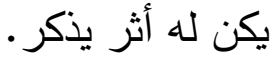

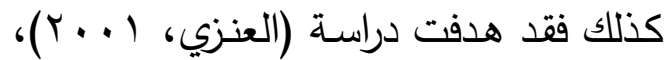
إلى الكثف عن متغيرات الرضا عن الحياة، والثقة بالنفس، والتفاؤل، والتوازن الوجداني لاى عينة من طلبة وطالبات كلية التربية الأساسية بالهيئة العامة للتعليم التطبيقي والتدريب بدولة الكويت. وبلغ قوام

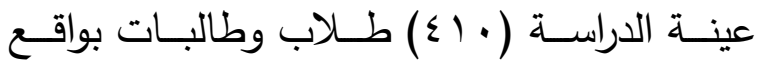

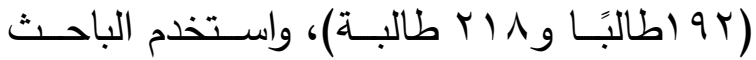
مقيـاس الرضــا عـن الحيـاة مـن وضــع "دينـر وزملائـه"، ومقيـاس التـوازن الوجداني مـن وضـع "نورمان" (بريد بورن) ويشتمل على جزأين هما: الوجدان الإيجابي والوجدان السلبي، ومقياس الثقة بالنفس من وضـع فريح العنزي ومقياس التفاؤل

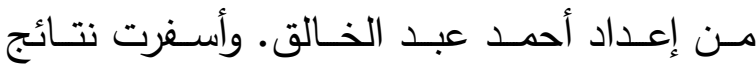




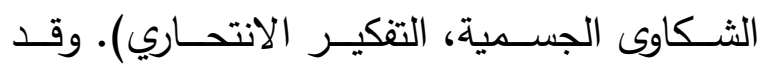
اسـخدمت في هذه الدراسـة عينـات متعددة مـن طـلاب الهيئة العامـة للتعليم التطبيقي والتدريب، ومـن طـلاب جامعـة الكويـت بواقـع سـبع عينـات، وبواقع ( • Y من طـاب الجامعة لإجراء السؤال

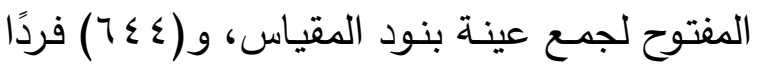
لفحص الفروق بين الجنسين. وقد أسفرت نتائج الدراسـة عـن تمتـع مقيـاس التفـاؤل غيـر الـواقعي بخصــائص قياسـية جيـدة مــن ناحيـة الثبـات والصدق، وقد كثفت نتائج التحليل العـاملي عن اسـتخلاص عـاملين (الأحـداث السـارة والأحـداث

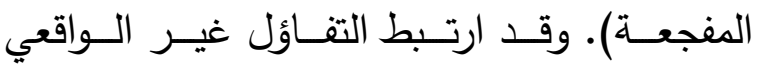
ارتباطـات جوهريـة موجبـة مـع التفـاؤل، في حين ارتـبط بارتباطـات جوهريـة سـالبة مـع كـل مـن التشـاؤم والقلق والوسواس القهري والذنب والخزي والثـكاوى الجسـمية واليـأس والاكتئـاب والتفكيـر

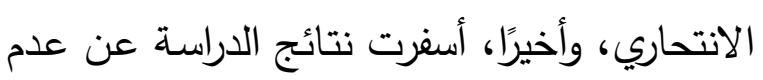
وجود فروق جوهرية بين الجنسين في التفاؤل غير

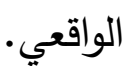

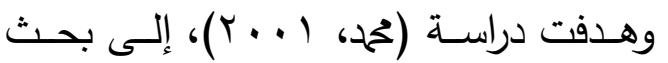
الإنجــاز الأكـاديمي وعلاقتـهـه بالتفــاؤل والتشــاؤم والدافعية وأساليب مواجهة المشكلات لدى طالبات كليـة التربيـة النوعيـة بـالفيوم (ن= بآ ( )، وقـــ طبقت على العينة عدة مقاييس تمثلت في مقياس التفــاؤل والتثــاؤم، ومقيــاس الدافعيـة، ومقيـاس أسـاليب مواجهـة المشكلات (المواجهـة الإقداميـة والمواجهة الإحجامية). وقـد كثـفت النتـائج عـن ثلاثـة معـاملات الات ارتباط موجبة مرتفعة بين الإنجاز الأكاديمي وكل
التفاؤل وكل من: الثـعور بالوحدة، وقلق الموت، ومصدر الضبط (الخارجي)، وكثفت النتائج عن علاقـة ارتباطيـة موجبـة بـين التشـاؤم وكـل مـن الثـعور بالوحدة، وقلق المـوت ومصـدر الضـبط (خـارجي). كمـا بينـت النتائج عدم وجـود علاقـة ارتباطية دالـة إحصـائيًا بين التفاؤل والتشـاؤم من جانب، والوضع الاجتماعي الاقتصادي من جانب آخر . كما لا توجد فروق في التفاؤل وفي التشاؤم بين أفراد عينـة الدراسـة مـن مستويات اجتماعيـة واقتصــادية مختلفــة. كـذلك توجـــــــروق دالــة إحصائيًا بين الذكور والإناث في متوسط التفاؤل

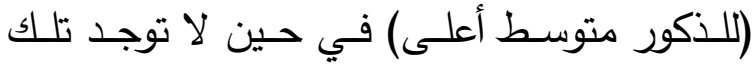
الغروق بينهما في متوسط التشاؤم. وأيضًا لا توجد فروق عمريـة دالة إحصـائيًا في التفاؤل والتشـاؤم، كما أنه لا توجد فروق في التفاؤل والتشاؤم نتيجة التفاعل بـين العمـر والجنس، وأخيـرًا كانـت أكثر المتغيـرات تتبـؤا بالتفاعـل هـيـ- علـى التـوالي الشعور بالوحدة، ثم وجهة الضبط، ثم قلق الموت، والوضــع الاجتمـــي الاقتصـادي، وكانـــ أكثـر المتغيـرات تتبـؤًا بالتثــاؤم علــى التــوالي وجهــة الضـبط، ثـم الثـعور بالوحـدة، ثـم قلـق المـوت، والوضع الاجتماعي الاقتصادي.

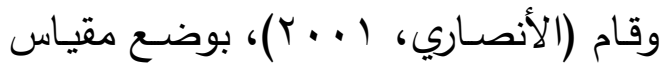
للتفاؤل غير الواقعي معتمدًا على المجتمع الكويتي على نحو خاص، ثم قاس الفروق الفردية والفروق بـين الجنسـين في التفـاؤل غيـر الـواقعي، وحـدد طبيعـة العلاقة بين التفاؤل غير الواقعي وبعض متغيـرات الشخصـية (التفــاؤل، التشــاؤم، اليــأس، الاكتئاب، القلق، الذنب، الخزي، الوسواس القهري، 
بخصائص قياسية جيدة بوصفه مقياسًا للتفاؤل، وقد كثف التحليل العاملي للاختبار عن استخراج عاملين هما التفاؤل والتشاؤم، وقد ارتبط التفاؤل

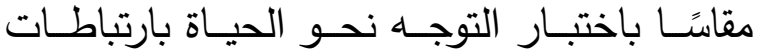

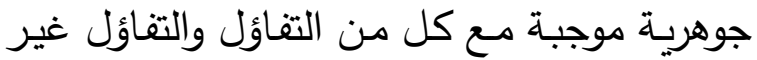
الواقعي ، في حين ارتبط بارتباطات جوهرية سالبة

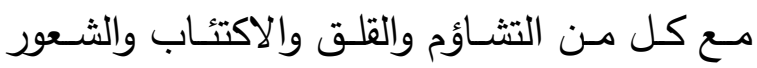
بالذنب والخزي واليأس والوسواس القهري، وكان الكور أكثر تفاؤلا من الإناث.

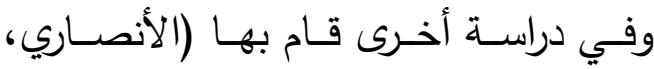
r . . r"ب")، هدفت إلى تحديد طبيعة العلاقة بين التفاؤل غير الواقعي، وبعض متغيرات الثخصية:

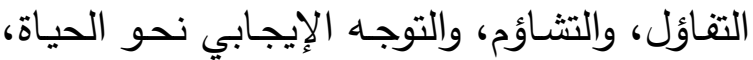
واليأس، والذنب، والخزي، وقد استُخدم في هذه ولنه الدراسة عينتان من طلاب جامعة الكويت - وذلك الكابل نظرًا لاختلاف المقـاييس التـي طبقت عليهمـا-

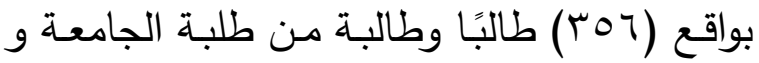

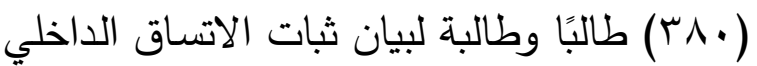
لكقــييس الدراســة، ولاســتخلاص الارتباطــات المتبادلة بين متغيرات الثخصية، وفحص الفروق

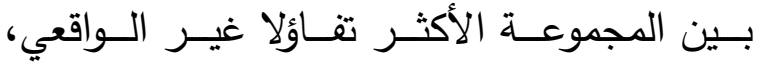
والمجموعة الأقل تفاؤلاً غير الواقعي في متغيرات

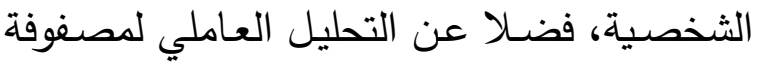
معـاملات الارتبـاط بـين متغيـرات الثخصـية. واستخدمت في هذه الدراسة مجموعة من الدقاييس هي: مقياس التفاؤل غير الواقعي، ومقياس جامعة

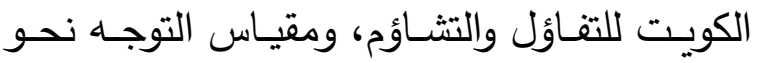
الحيـاة، ومقيـاس بيك لليـأس، ومقيـاس الـنتب، ومقياس الخزي. وكثفت نتائج الدراسة عن ارتباط
من الدافعية والتفاؤل والمواجهة الإقدامية، ومعامل ارتبــاط دال وسـلبي بـين الإنجــاز الأكـاديمي

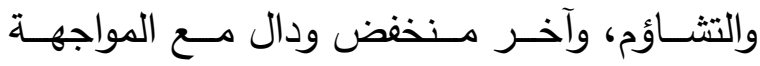
الإحجاميـة، ومغزىى هـذه الارتباطـات هـو تـأثر الإنجـاز الأكـاديمي بـالمتغيرات الددروسـة، فكلهـا ازدادت الدافعية والتفاؤل والمواجهة الإقدامية ازداد

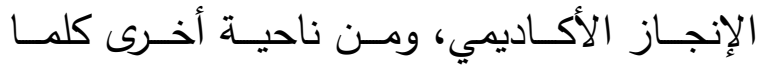
انخفـض التشــاؤم والمواجهـــة الإحجاميــة، ازداد

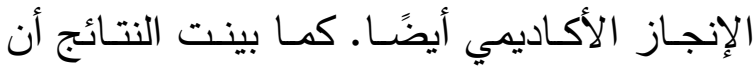
التفاؤل والتثاؤم يؤثران بصورة دالة في الإنجاز الأكاديمي بدرجـة أو بأخرى، وقد كثفت النتائج عن أنه يمكن التنبؤ بالإنجاز الأكاديمي من خلال

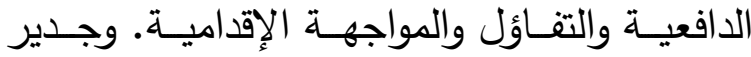
بالذكر الإثارة هنا إلى ما بينته النتائج من ارتباط التفاؤل بالتثاؤم سلبيًا، فهذا يشير إلى بقاء مشكلة النظر إليهما (باعتبارهما سمة ثنائية القطب، أو لئاه أنهما أبعاد مستقلة نسبيًا أو مفاهيم مستقلة ولكنها

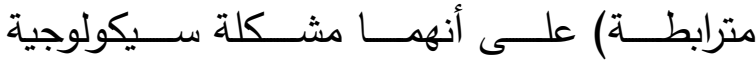
وسيكومترية، كما أن هذه النتيجة تعضد قياس كل منهما بصورة مستقلة كما في الدراسة الحالية (من خلال اختبار التوجه الايجابي نحو الحياة كمقياس للتفاؤل)، حيث إن القياس المستقل لا يعني انعدام التداخل بينهما في تأثيرهما. وقــام (الأنصــاري، ؟ ... ץ "أ")، بدراســة هدفت إلى إعداد صورة عربية من اختبار التوجها نحو الحياة الذي أعده كل من ( Scheier, and Carver, 1985 )، وتحديـ معالهـه السيكومترية، وفحص ارتباطاته ببعض متغيرات الثخصية، وقد أسـفرت نتـائج الدراســة عـن تمتــع الاختبـــار 


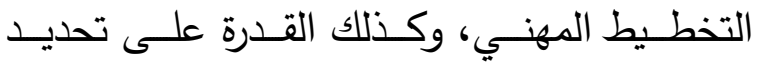
الأهـداف المرتبطــة بـالمهن التـي يعملـون بهــا، وبالنسـبة للرفاهيـة فقـــــرر أصــحاب الـدرجات المرتفعـة في التفاؤل مستويات مرتفعـة من تقدير الـذات ومسـتويات منخفضــة مـن الوقـوع فريسـة

$$
\text { للكروب النفسية. }
$$

وفي دراسـة قام بها كل مـن (Brissett;

2002 التعـرف إلــى الــدور الـــي تقـوم بــه المســاندة الاجتماعيـة والقدرة على مواجهة المشكلات، في ارتفاع التفاؤل لدى الفرد، وكذلك قدرة الفرد على أن يكون لايـه توافق أفضل عند مواجهة ضـغوط أحـداث الحيـاة. وللتحقـق مسن هـذا طبقـت عـدة مقـاييس علـى عينــة مـن طـلاب الجامعـة مـن الجنسـين، وهــذه المقــييس هـي : مقيــاس إدرالك الضـــوط، ومقيــاس الاكتئـاب ومقيــاس إدراك المسـاندة الاجتماعيـة، وأخيـرًا التعـرف إلى حجى التم شبكة العلاقات الاجتماعيـة لدى الأفراد والممثلة

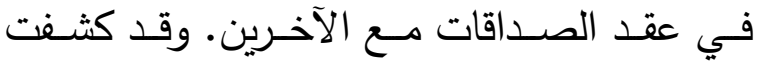
الدراسـة عن علاقـة ارتباطيـة بين ارتفـاع التفاؤل وتلقي الفـرد للمسـاندة الاجتماعيـة، وكذلك قدرتهـ على مواجهة المشكلات Coping، بمعنى أنه كلما

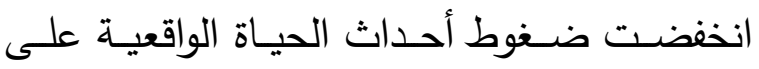
الطـلاب من الجنسين، زاد التفـاؤل، ونفس الحسال مع الاكتئاب فإذا انخفضت درجة الاكتئاب زادت درجة التفاؤل.

وقام كل من Gautier, Raufaste, and

بترجمـة وتقنين اختبار التوجـه Carious, 2003) نحو الحياة المُعدل، ثم قاموا بتطبيقهـ على عينـة
التفاؤل غير الواقعي بارتباطات جوهرية موجبة مع التفاؤل، والتوجها الإيجابي نحو الحياة، في حين ارتـبط بارتباطـات جوهربــة سـالبة مـع كـل مـن التشـاؤم، والــذنب، والخـزي. كمـا كثـفت نتــائج التحليل العـاملي عن عـاملين (عامل التفاؤل في مقابـل اليـأس، وعامـل الـذنب والخـزي). وأخيـرًا أسفرت نتائج الدراسة عن وجود فروق جوهرية بين المجموعتين (الأكثر والأقل تفـاؤلا غير الواقعي) في متغيرات الشخصية، حيث تميزت المجموعـة الأقَل تفـاؤلا غير الـواقعي بمتوسطات أعلى مـن المجموعة الأكثر تفاؤلا غير الواقعي في كل من التثـاؤم، واليـأس، والــنـب، والخـزي، فـي حـين تميزت المجموعة الأكثر تفاؤلا غير الواقعي عنها

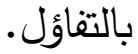

(Creed, Patton, Barturn, وهدفت دراسة

(2002 إلى التعرف إلى الخصـائص السيكومتريـة لمقياس التوجه نحو الحياة المُعدل، وكذلك معرفة تـأثير التفــاؤل والتشــاؤم علــى المهنـــة والهنــاء "السعادة"، وارتباطهما ببعض المتغيرات لدى عينة مـن المـراهقين قوامهـا (0 . ع) مـن الطــلاب مـن

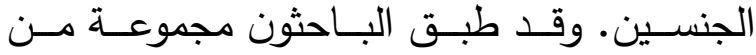
المقاييس تمثلت في: مقيـاس التوجـه نحو الحياة المُعدل، ومقياس النضـج المهني، ومقياس اتخـاذ القرار المهني وأخيرًا مقياس الأهداف المهني. وقد كثفت نتائج التحليـل العـاملي التوكيدي لمقيـاس التوجـهـ نحـو الحيـاة المُعـدل عـن عـاملين همـا: التفـاؤل والتشـاؤم، كمـا بينـت النتائج أن أصـحاب الـدرجات المرتفعـة في التفـاؤل قـرروا مسـتويات مرتفعـة مـن التقــة في اتخـاذ القـرار ، القدرة على 


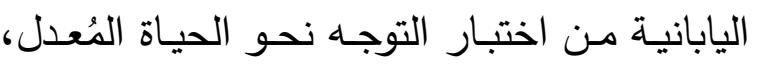
وذلكـ على عينـة مـن طـلاب الجامعــة اليابانيـة

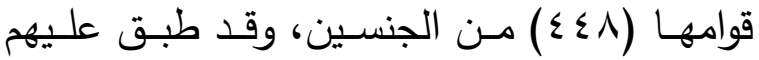
أيضًا ثلاثـة مقاييس هـي الانبسـاط، العصـابية، والاكتئاب. وقد كثفت نتائج التحليل العاملي عن عـاملين هــا: التفـاؤل والتشــاؤم، الأول "التفـاؤل" ارتبط بالعبارات الإيجابية، والثاني "التشاؤم" ارتبط بالعبارات السلبية من الاختبار ـ وقد بينت نتائج

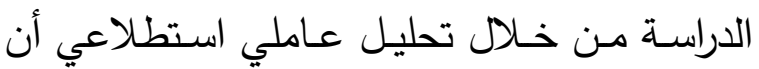

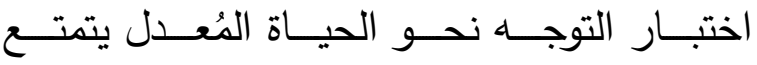
بخصـائص سيكومترية مقبولـة. Acceptable وقد

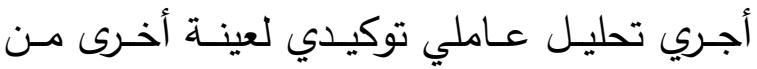

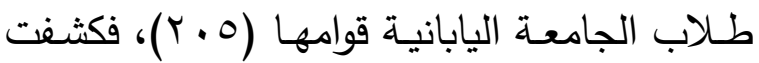
النتائج أيضًا عن عاملين هما التفاؤل والتثاؤم وأن

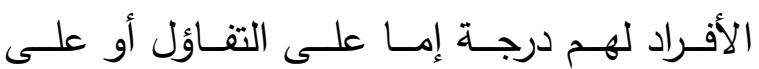

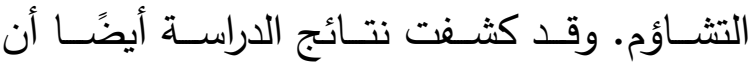
العبـارات الإيجابيـة التي تعبـر عـن التفــاؤل قدـ ارتبطت إيجابيًا بالانبساط (ارتباط جوهري دال)، كما ارتبطت سلبيًا مع الاكتئاب والعصابية (ارتباط

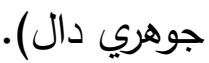

وفي دراسة (Reilley, et al., 2005) بُحث

التفاؤل والتثاؤم باعتبارهما متغيرين من متغيرات الثخصية يؤثران على الصـحة العضـوية للفرد، والقدرة على أداء العمل، والعلاقـات الاجتماعيـة التي تقوم بين الأفراد بعضهم بعضًا، وللتحقق من هذا قام الباحثون بثلاث دراسات: الأولى: كانت

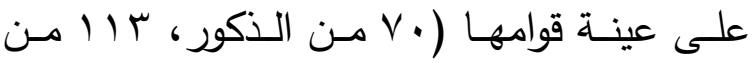
الإنـاث) مـن طـلاب الجامعـة، وقد طبق عليهمـا مقياسان هما: استخبار (Peterson, et al., 1988)؛

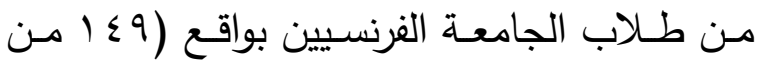

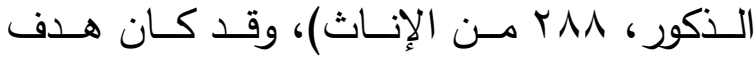
الدراســة الأساسـي هـو التــــف إلـى مـا إذا كـان

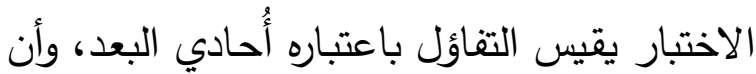
الأفراد إما أن يكونوا متفائلين أو متثائمين، أم أنه يقيس التفاؤل باعتباره ثنائي البعد أي أن الأفراد يقعون على متصل يمتد من التفاؤل إلى التشاؤم والعكس، وللفرد درجة على هذا وذاك، بمعنى أن الأفراد لا يكونون متفائلين فقط أو متثائمين فقط،

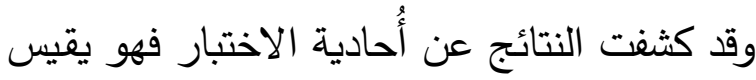

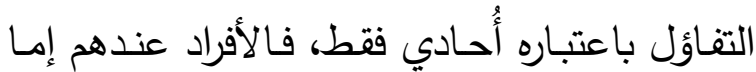
متثـائئين أو متفائلين وليس للفرد درجتان على

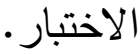

أمـا (سـلامة، ع . . ץ)، فقد هدفت دراستها

إلى بحث العلاقـة بين كل من التفاؤل والتثـاؤم والتقدير الذاتي للأغراض الجسمية والنفسية للى لإن عينـة مـن طـلاب جامعـة الكويت (بر ا طالبًا، • r ا طالبـة). وقـد كثـفت الدراسـة عـن علاقـة ارتباطيــة سـالبة دالــة بـين التفــاؤل وكـلـ مـن الأعراض الجسمية والوسواس القهري والاكتئاب والقلق، والحساسية التفاعلية، والعداوة، والمخاوف المرضية، والبارانويا، والذهان، وذلك لدى كل من الذكور والإناث، في حين كانت جميع الارتباطات السابقة موجبـة دالة بالنسبة لمتغير التشـاؤم لدى الدى كل من الذكور والإناث، ولم تكثف الدراسة عن وجود فروق دالة بين الأكور والإناث على متغيري

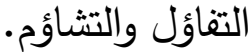

وفي دراسـة قـام بهـا (Nakano, 2004) للتحقـق مـن الخصــائص السـيكومترية للنسـخة 
et al., 1988) التي تتسم بالتفاؤل (ارتباط موجب) في حين يرتبط

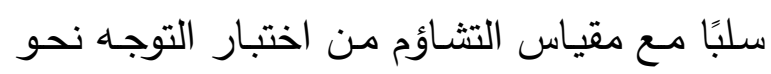
الحياة والتشاؤم من استخبار "بيترسون" ومقياس

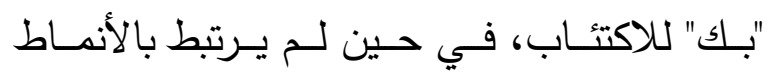

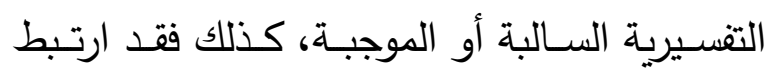
"التفاؤل" من اختيار التوجهـ نحو الحياة ارتباطًا

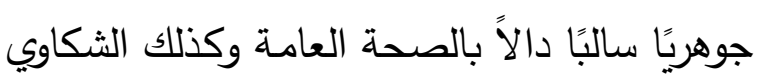

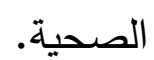

وقام (عبد الخالق، ه . . ب)، بتطبيق القائمة

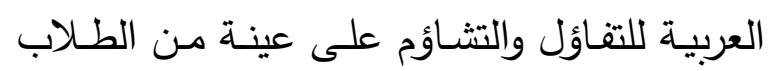

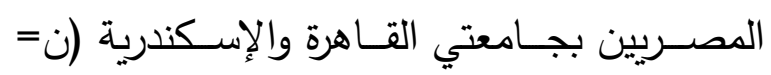

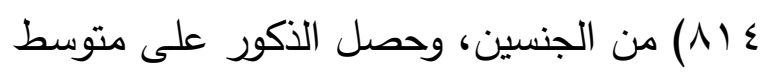

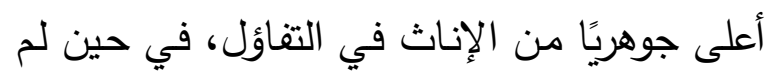

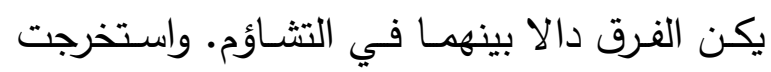
ارتباطـات سلبية جوهريـة بين التفاؤل وكل مـن التثـاؤم، وجنس الإنـاث، والقلق، في حين كـان الارتباط موجبا بين التثاؤم والقلق. وقد استخرج من التحليل العاملي لبنود المقياس الفرعي للتفاؤل عامل واحد جوهري، ومثله في مقياس التشاؤم.

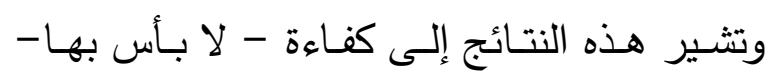
للقائمة على العينات المصرية.

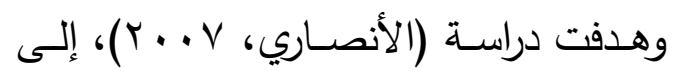

فحص الكفـاءة القياسية للقائعـة العربيـة للتفـاؤل والتثـاؤم لدى ثماني عشرة دولة عربيـة. هذا من

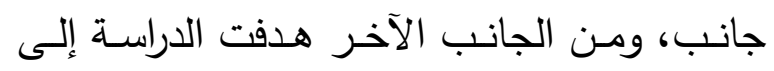

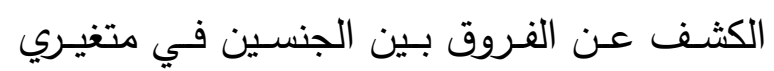
التفاؤل والتثاؤم، مع تبين طبيعة علاقات الارتباط

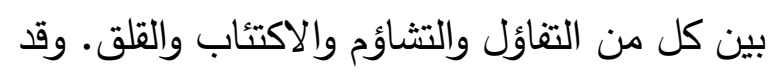

وهو مقياس للتفـاؤل والتثــاؤم، ومقياس الصـحة العضوية الذي أعده (Lin and Peterson, 1995).

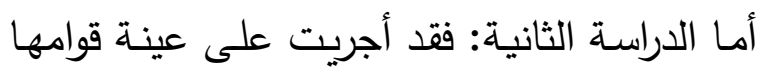

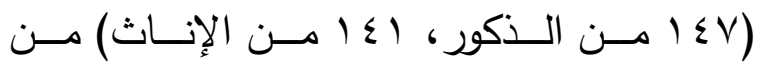
الدارسين الملتحقين بأحد برامج علم النفس، وقد الإند طبق عليهم (r) مقاييس هي: اختبار التوجه نحو لئحسن الحياة (Scheier, et al., 1985)، واستخبار النمط التفسيري (Seligman, 1979) واستخبار التفاؤل والتشاؤم (Peterson, et al., 1988). ، أما الدراسة

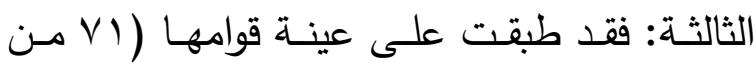
الذكور، ب rا من الإناث)، من الطلاب الملحقين

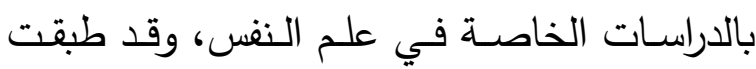
عليهم الأدوات السـابقة ذاتها في الدراسـة الثانيـة

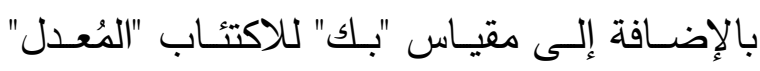
(Beck, et al., 1979)، وكذلك بطاريـة التفكير الاستتناجي أو البنـئي (Thinking Inventory (CTI) (Epstein and Meier, 1989)

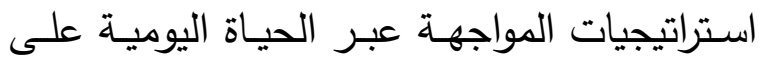
مقياس يتدرج من (0) نقاط تبدأ من بالقطع خطأ

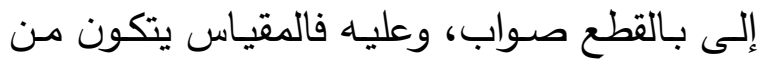
مقياسين فرعيين احدهما يقيس أساليب المواجهة

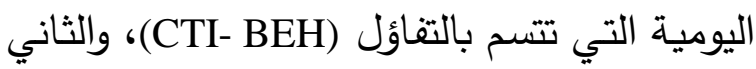
أسـاليب المواجهة التي تتسم بالتثـاؤم ويرمز لها لهائ بالرمز (CTI- EMOT). وقد بينت النتائج أن اختبار التوجـه نحو الحياة يتكون مـن مقياسين

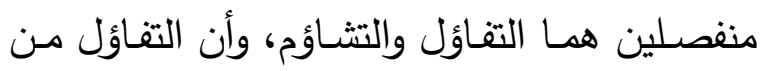
اختبار التوجهـ نحو الحياة يرتبط ارتباطًا جوهريًا

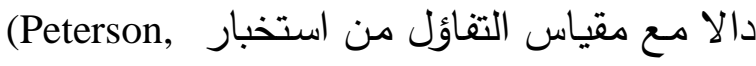




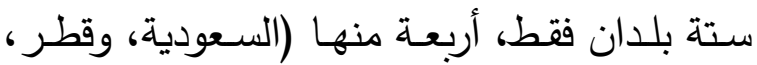
والإمـارات، والمغـرب) أظهـرت أن الــكور أكثـر تشاؤمًا من الإناث، في حين كانت الإناث أكثر تشاؤمًا من الذكور في العراق وليبيا فقط.

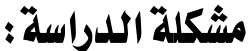

بنـاء على الدراسـات السـابقة، وفي ضـوء نتائجها فقد اتضح أن التوجه الإيجابي نحو الحياة أو التقاؤل يمثل أحد العناصر المهمة لإيجاد بنية نفسية صـحيحة للفرد، كما أنـه يسهح بشكل فعال

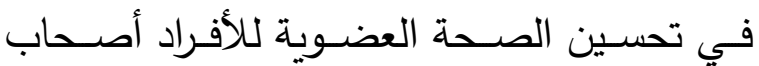
التفاؤل، كمـا أنـه يرتبط إيجابًا بعدد مـن السمات النفسية الشخصـية والاجتماعيـة منهـا: الانبسـاط، والاعتــداد بالـــذات وتقــديرها، والثقـــة بــالنفس، والطمأنينـة، والحالات المزاجية الإيجابية اليوميـة، والمســاندة الاجتماعيــة، والقــدرة علــى مواجهــة المشكلات وضغوط أحداث الحياة، وكذلك التقدير

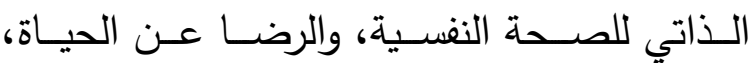
والسعادة، كما يرتبط سلبًا بالعصابية، والقلق، وقلق المـوت، والاكتئـاب، ومتغيـرات الوجـدان السـلبي، توني، والثـعور بالوحـدة النفسـية، والنرجسـية، واليـأس، والتشـاؤم، كذلك فهـو مُنبـــ بعـدد مـن متغيـرات الصحة النفسية والعضوية. غير أن ما لم تتطرق إليه الدراسات السابقة يتمثل فيما يلي: ا ـ الكثف عن الفروق بين الجنسين على تلك

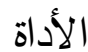

r. بحـث اتجاهـات الفـروق بينهمــا علـى بنـود اختبار التوجه نحو الحياة "المعدل" (ج بنود)
طبقــت القائمــة العربيـة للتفــاؤل والتشــاؤم، على عينـات مـن الطلبـة العـرب بجامعـات مـن ثمانيـة

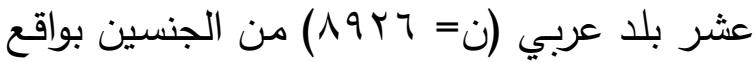

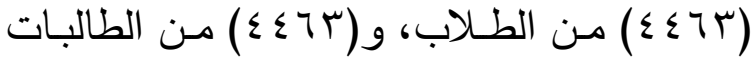

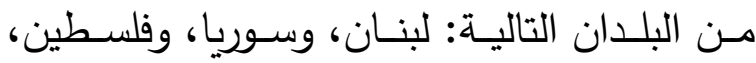
والأردن، والعراق، والسعودية، والكويت، والبحرين، وقطـر ، والأمــارات، وعمــان، والـيمن، ومصـر والسـودان، وليبيـا، وتـونس، والجزائر ، والمغـرب،

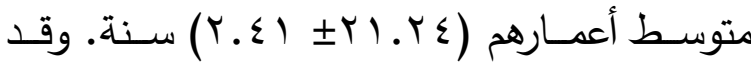
أسفرت نتـائج الدراسـة عـن تمتـع القائكـة العربيـة للتفاؤل والتشاؤم بخصائص قياسية جيدة من ناحية الثبات والصدق، كما كثفت نتائج التحليل العاملي لبنـود المقيـاس الفرعي للتفــاؤل عـن اسـتخلاص عامل واحد جوهري، ومثلـه في مقيـاس التشـاؤم، واستخرجت ارتباطـات سلبية جوهريـة بين التفاؤل وكـل مـن: التشـاؤم، والاكتئـاب، في حـين كـان الارتباط موجبًا بين التشاؤم والاكتئاب والقلق. وقد كشـفت نتـائج الدراســة أيضًا أن التفـاؤل والتشــاؤم عبـارة عـن ســتين مسـتقلتين ولكنهــا مترابطتـان بوسيط قدره (ر= - (0). )، وتشير هذه النتائج إلى كفـاءة- لا بــأس بهـاـ- للقائمسة على ثمانيـة عشر بلدًا عربيًا. وأخيرا أسفرت نتائج الدراسة عن وجود فروق جوهريـة بين الجنسين في التفاؤل في سبعة بلدان عربية أظهرت أن الذكور أكثر تفاؤلا من الإناث في سبعة بلدان عربية هي: (العراق، وعمـان، ولبنـان، والكويــت، والسـودان، وسـوريا، ومصر )، في حين كانت الإنـاث أكثر تفاؤلا من الذكور في السعودية فقط، كما كشفت النتائج عن وجود فروق جوهرية بين الجنسين في التشاؤم في 
أهمية اللدراسة :

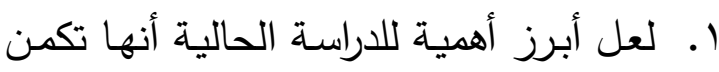

فـي اختيـار اختبـار التوجـهـ نحــو الحيـاة "المُعـدل" والمستخدم في الدراسـة الحاليـة، والذي قام الباحث بتعريبه وحساب خواصـه

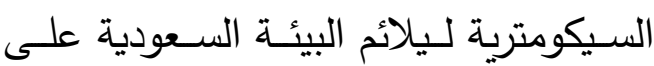
وجه الخصوص والعربية على وجه العموم. r. أنه يقيس مفهومًا يُعد من الدفاهيم الأساسية

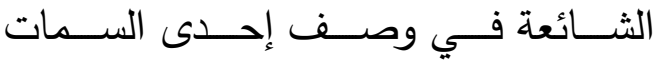
الثخصية وقياسها، وهو "التفاؤل".

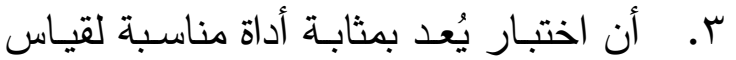
سمة "التفاؤل". إذ من المعلوم أنه يوجد عدد قليل من الاستخبارات النفسية التي تقيس سمة التفاؤل مقارنة بعدد الاستخبارات التي لالتي تقيس السمات الثخصية الأخرى كالقلق،

$$
\text { والاكتئاب ....إلخ. }
$$

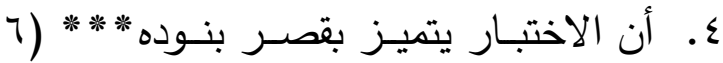

بنود) ممـا يسهل على المبحوثين الإجابـة

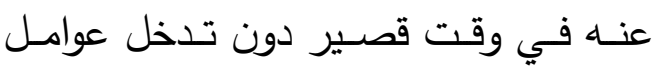
الملل والإهمال، وهذا بدوره ينعكس إيجابيًا على النتائج المرجوة من الاختبار .

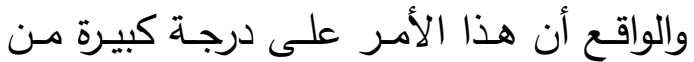
الأهميـة، ذلـك أن كثيـرًا مـن البـاحثين تـواجههم مشكلة في عدم رغبة المبحوثين في الإجابة عن جميع بنود المقاييس نظرًا لشعورهم بالسأم والملل r. إعـداد أداة عالميـة مترجمـة ومعربـة مـن قبـل الباحث للبيئة السعودية ع. بيان أن التفاؤل والتثاؤم سمتان يمكن قياسهما بنجـاح بوسـاطة اختبـار التوجـه نحو الحيـاة المعدل - الم

وهذا في جملته ما تسعى إليه الدراسة الحالية وما تتميز به عن الدراسات السابقة

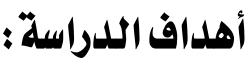

\section{يمكن تحديد أهداف الدراسة فيما يلي:}

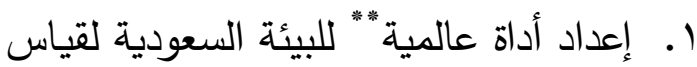
التوجـه نحـو الحيـاة وهي اختبـار التوجـهـ

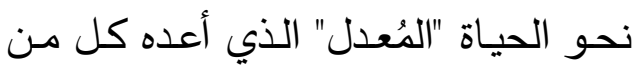
(Scheier; Carver and Bridges,1994) باعتباره مقياسًا للتفاؤل، والتي يمكن أن

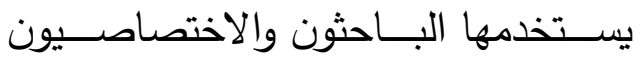
النفسيون في مجـال البحـوث الحضـارية

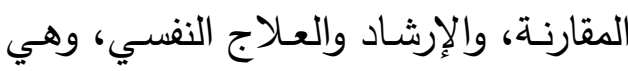
التعـرف إلى الفـروق بـين الجنسين في

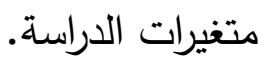
r. التعرف إلى الفروق بين الجنسين على بنود اختبار التوجه نحو الحياة المُعدل. r. أن التفـاؤل والتشــاؤم يمكن النظر إليهمـا

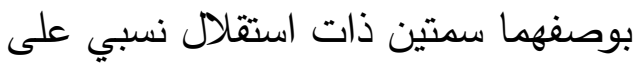
الرغم من الارتباط الجوهري بينهما، وأنـه يمكن قياسـهما بنجـاح بوسـاطة اختبـار التوجه نحو الحياة المعدل.

"*" يوجد في الساحة العربية بالكويت تعريب لاختبار التوجه

نحو الحياة، وهو يتكون من (^) بنود، وقد أعده وحسب

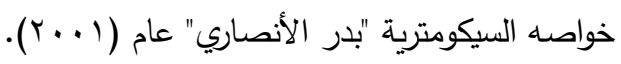




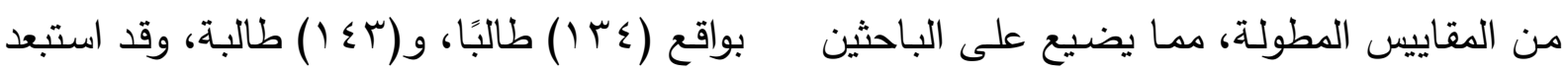
الباحث استجابات عدد من الطلاب من الجنسين الـذين لـم يكملـوا بيانـات بعـض بنـود بطاريــة الاختبارات، وبالتالي تكونت العينة النهائية للدراسة من (Y ) من طلاب وطالبات الجامعة موزعين على النحو التالي:

1- عينة الذكور : وهي تتكون من (11) من (1)

$$
\text { الذكور من طلاب الجامعة. }
$$

Y- عينة الإناث: وهي تتكون من (T I ( ) من

$$
\text { الإناث من طالبات الجامعة. }
$$

وجميع أفراد عينـة الدراسـة متجانسين مـن

حيث العمر حيث تراوح المدى العدري لهم ما بين

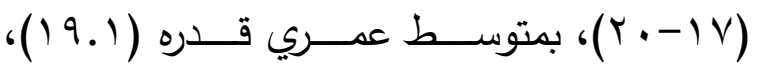

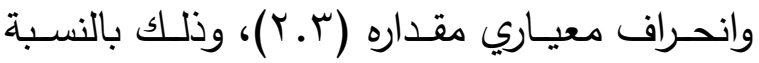

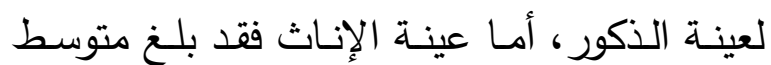

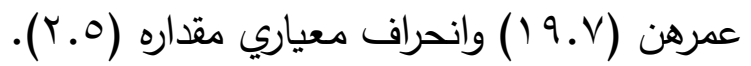
ب- أداة الدراسية:

استخدم الباحث في الدراسـة الحالية اختبار

التوجه نحو الحياة المُعدل باعتباره مقياسًا للتفاؤل وهو من تأليف (Scheier and Carver, 1994)؛ وقد قام الباحث بتعرببه وتقنينه. وفيمـا يلي يعرض الباحث للاختبـار على النحو التالي:

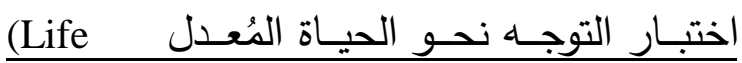
Orientation Test-Revised (LOT-R) وضـع كل من Scheier; Carver and Bridges,1994)

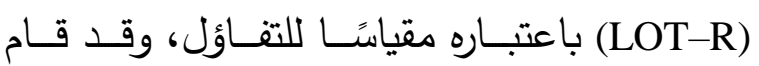
الباحث بتعريبه وإعادة تقنينه على عينة من طلاب جهودهم في الحصول على العينة الكافية للبحث أو حصولهم على نتائج تفتقد المصداقية، من جهة أخرى يساعد قصر الاختبار على إمكانية تطبيق بطاريــة مـنـ المقــاييس النفسـية المتعـددة التـي يحتاجها الدارس لدراسة ظاهرة ما. 0. يُعد اختبار التوجه نحو الحياة "المعدل"، من الاختبـارات التي انتشـر استخدامها عالميًا لقيــاس ســمة التقــاؤل لــدى المــراهقين والراشدين. (الأنصاري، ؟ . . ץ"أ")

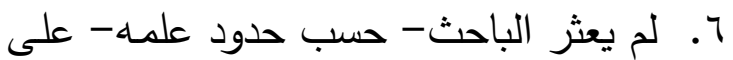
دراسة سابقة استخدمت اختبار التوجه نحو الحيـاة "المُعـدل" في المجتمـع السـودي أو العربـي على النحو المستخدم في الدراسـة الحالية والذي تسعى إليه من خلال التحقق من صحة فروض الدراسة الحالية. فروض الدراسةة : - ماس

ا- توجـد فروق جوهريـة بـين الجنسـين في التوجه الإيجابي نحو الحياة "التفاؤل". r- توجد فروق جوهريـة بـين الجنسين على بنود اختبار التوجه نحو الحياة المُعدل. r- التفاؤل والتشاؤم سمتان يمكن قياسهما بنجاح بوساطة اختبار التوجه نحو الحياة

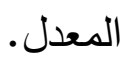

\section{منهج الدراسة وإجراءاتها:}

أ- عينة الدراسةة:

تم التطبيق على أفراد عينـة الدراسـة بشكل جمعي، وقـد كـان قـوام العينـة الأساسـية للدراســة مكونتًا من (rVV) طلاب الجامعـة من الجنسين، 
عامـل واحــ للاختبـار أطُلـق عليـهـ استم "عامـل

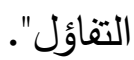

وقد استخُدمت للإجابة على بنود مقياس

التوجه نحو الحياة بدائل خماسية هي:

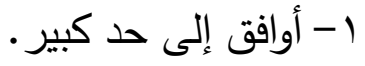
r- أوافق بقدر ضئيل. ك- أو أوافق ولا أعارض. ع- أعارض بقدر ضئيل. 0- أعارض إلى حد كبير.

الخصـائص السيكومترية للاختبــار في اللدراسـة

الحالية أولا : الثبات

حُسب ثبات الاختبار وصدقه على عينـة

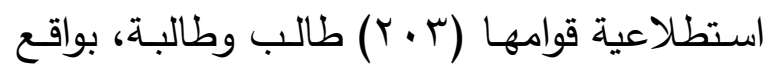

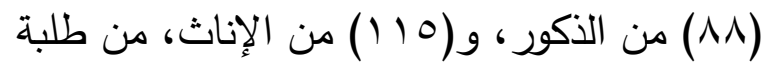

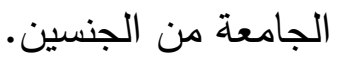

وفيما يلي عرض لطرق الثبات:

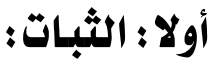

حُسب الثبات بطريقتين هما:

1- التطيق وإعادة التطيقي: "ثات الاستقلرا":

طبق الاختبـار على عينـة التقنين بفـارق

زمني شهر ، وفيما يلي عرض لنتائج معاملات الارتباط بين التطبيق الأول والثاني: جدول رقم (1) يوضح معاملات ثبات الاستقرار لاختبار التوجه نحو الحياة المُعلدل لاى العينات الثلاثة لئل

\begin{tabular}{|c|c|c|c|}
\hline الدلالة & لداملاتلات ثبات الإنتاث & الدلالة & الاستقرار \\
\hline$\ldots$. & r.Aor & $\ldots$. & $\therefore V \leqslant Y$ \\
\hline
\end{tabular}

الجامعـة وطالبتها، وفيمـا يلي وصف للاختبار ،

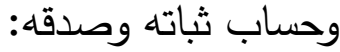

وصف الاختبار:

وضع أول اختبار لقياس التوجه نحو الحياة

(Scheier and كل من Life Orientation Test Carver, 1985) وقد كان المقياس يتكون من

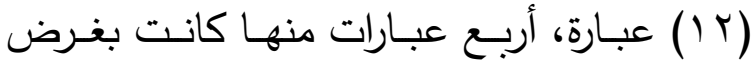

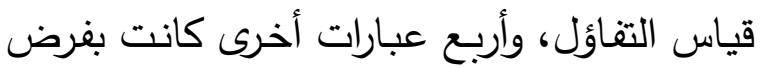
قيـاس التثــاؤم، والعبـارات الأخيـرة (ع عبـارات)

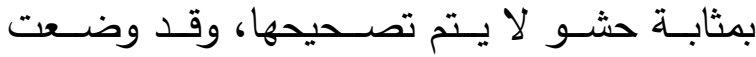
بغرض إخفاء الهدف من المقياس، وقد تعرض لاس المقياس لعدد من أوجه النقد، منها أنه يعد بمثابة مقياس للعصابية وليس للتفاؤل والتشاؤم. (Scheier; Carver, Bridges, وقد ذكر (1994 أن اختبار التوجـه نحـو الحيـاة، يعد مـن الاختبـارات ذات الانتثـار والتي استخدمت في الإني العديد من البحوث، وبرغم هذا فقد عانى الاختبار

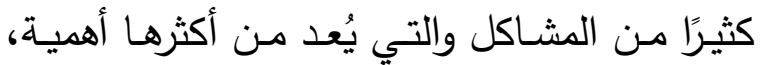

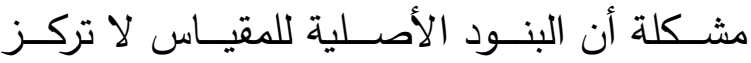

بوضوح explicitly على التوقعات المستقبلية. وبسبب هذا، ولعلاج هذا النقص- إلى حد ما كما يقول الباحثون- قام "ثاير وكارفر

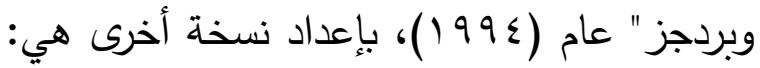

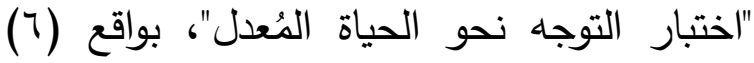
عبارات تثير بشكل عام لقياس استهداف التفاؤل.

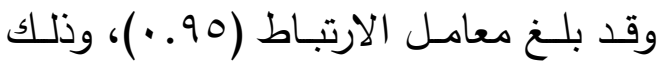
بين الصورة المُعدلـة (LOT-R)، والصـورة الأولى لـى للمقياس (LOT)، وهـو معامـل مقبول إحصـائيا،

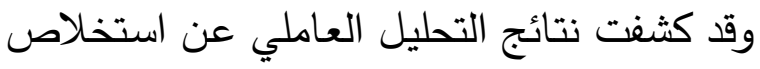




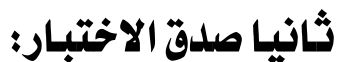

حسب صدق الاختبار على النحو التالي الصدق التقاربي والاختلافي:

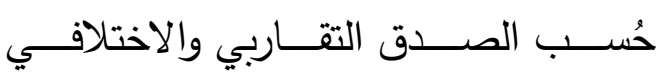

للاختبـار ، وذلك مـن خـلال حسـاب الارتباطـات المتبادلة بين الاختبار وكل من المقاييس التالية: التفاؤل، والتشاؤم، والتفاؤل غير الواقعي، والرضـا

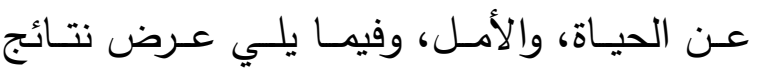
معساملات الارتبـاط بـين الاختبـار وغيـره مـن

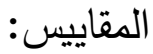
جدول رقم ( ) يوضح معاملات الارتباط المتبادلة بين اختبار التوجه نحو الحياة المُعدل وبعض المقاييس لاى الجنسين

\begin{tabular}{|c|c|c|}
\hline الدلالة & اختبار التوجه نحو الحياة الارتباط مع & المقاييس \\
\hline & & التفاؤل \\
\hline$\cdots \cdots$ & $\bullet . \wedge \vee$ & التشاؤم \\
\hline$\cdots+1$ & $. .77-$ & التفائل غير \\
\hline$\ldots \cdots$ & $.7 V-$ & الواقعي \\
\hline$\cdots \cdots$ &.$V 7$ & الرضا عن \\
\hline$\ldots \cdots$ &.$\vee \wedge \wedge$ & الحياة \\
\hline$\ldots \ldots$ &.$V Y$ & الأمل \\
\hline & & السعادة \\
\hline
\end{tabular}

مـن الجـدول السـابق نسـتنتج أن اختبـار

التوجهـ نحو الحياة بوصفه مقياسًا للتفاؤل يرتبط

إيجابيًا بالتفاؤل، والتفـاؤل غير الـواقعي، والرضـا

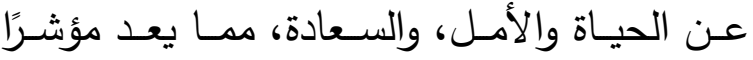
لصددق اتفاقي للاختبار ، على حين يـرتبط سـلًا

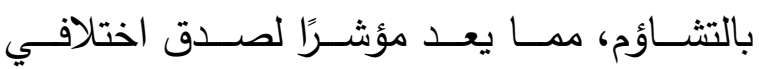

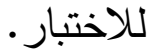

ب- حساب ثبات الاتساق الداخلي للاختبار: قام الباحث بحساب ثبات الاتسـاق الداخلي للاختبار بطريقتي معاملات ثبات ألفا - كرونباخ، والتجزئة النصفية، وفيما يلي عرض لتلك النتائج: (1) الثبات بطريقة ألفا - كرونباخ: جدول رقم (Y) يوضح معاملات ثبات ألفا- كرونباخ لاختبار التوجه نحو الحياة المُعدل لاى الجنسين

\begin{tabular}{|c|c|}
\hline $\begin{array}{c}\text { - كعاملات ثبات ألفا } \\
\text { كرونباخ لدى }\end{array}$ & كرونباخ لدى الذكور \\
\hline.$\vee V \vee T$ &.$\wedge T V$ \\
\hline
\end{tabular}

(Y) (الثبات بطريقة التجزئة النصفية: جدول رقم (ץ) يوضح معاملات ثبات التجزئة النصفية لاختبار التوجه نحو الحياة المُعدل لاى الجنسين

\begin{tabular}{|c|c|c|c|c|}
\hline الدلالة & الجزئين & ثبات_التجزئة & الجزئين & لالتجزئة النصفية ثلات الذبات \\
\hline$\ldots+1$ & $\ldots .$. &..$\wedge 9 \mathrm{~V}$ & $\ldots \ldots$ & $\cdot .9 \cdot r$ \\
\hline
\end{tabular}

ويتضـح مدـا سبق ارتفـاع معـاملات ثبات الاختبار، فالطريقة الأولى (ثبات الاستقرار) تشير نتائجهــا بوجـهـ عـام إلـى أن معــاملات ثبــات الاستقرار للاختبار مقبولة، كما أن ارتفاع معاملي ثبـات ألفـا - كرونبـاخ، وثبـات التجزئـة التصـفية تشيران إلى اتساق داخلي مرتفع للاختبار ، ومن ثم تعد هي الأخرى مقبولة إحصائيا بوجه عام. 
أولا : بـالنسـبة لــتفير التوجسـه نــــوالحيــاة

النتائج ومناقشتها:

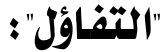

تثـير النتيجـة إلـى أن الذكور مـن أفراد

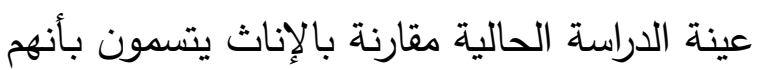
ذوي نظرة إيجابية، وهم الأكثر إقبالاً على الحياة

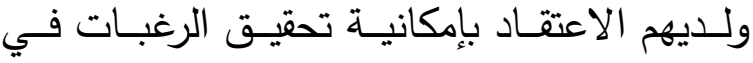
المستقبل، بالإضافة إلى الاعتقاد باحتمال حدوث

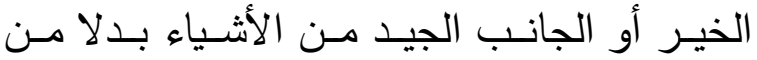

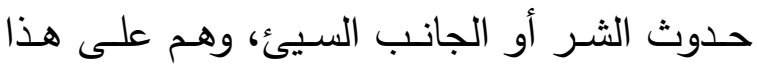
النحو لديهم استعداد عام يكمن داخلهم يتضمن

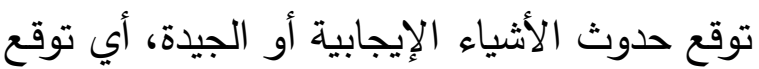

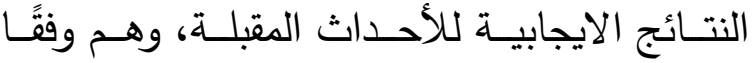
لتوقعـاتهم التفاؤليــة تجـاه الأحـــاث المسـتقبلية

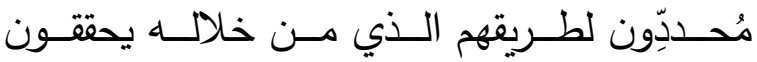

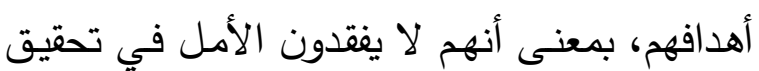
أهدافهم، كذلك فإن نظرتهم نحو المستقبل إنما هي لهي

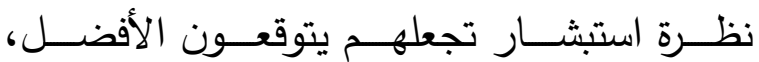

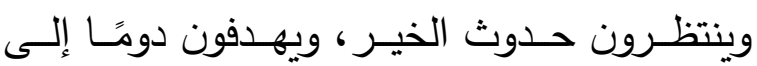
النجاح، ويستبعدون أي شيء غيره. وقد اتفقت هذه النتيجة مع نتائج دراسات كـل مسن (شـقير، 999 (؛ العنـزي والمشـعان،

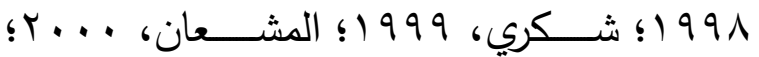

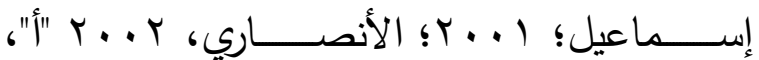

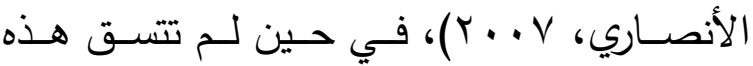
Shazia and Ghazala, ) النتيجـة مـع دراســا 2000)، التي بينـت أن الإنـاث أكثر تفــاؤلاً مـن

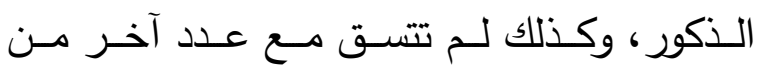
الاراسات التي لم تجد فروقًا دالة بين الجنسين في

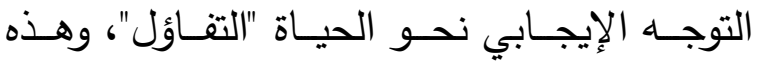

يعرض الباحث فيما يلي لنتائج الدراسة، وذلك على النحو التالي:

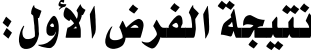

نص الفرض الأول على مـا يلي: "توجد فروق جوهريـة بين الجنسين في التوجه الإيجابي نحو الحياة "التفاؤل". جدول رقم (0) المتوسطات الحسابية والانحرافات المعيارية وقيم (ت) على مقياس التوجه الإيجابي نحو الحياة المُعدل لاى الجنسين

\begin{tabular}{|c|c|c|c|c|c|c|}
\hline \multirow{2}{*}{ الدلاد } & \multirow{2}{*}{ "ت" } & \multicolumn{2}{|c|}{ الإناث } & \multicolumn{2}{|c|}{ الذكور } & \multirow{2}{*}{ النوع } \\
\hline & & $\varepsilon$ & r & $\varepsilon$ & 1 & \\
\hline .1 & $r$. & $\varepsilon$. & $1 \leq$ & 0. & 10 & التوجه نحو \\
\hline & 09 & $\leqslant 9$ & $\begin{array}{r}r \\
r\end{array}$ & $7 \varepsilon$ & $\begin{array}{l}.9 \\
r\end{array}$ & "التفاؤل" \\
\hline
\end{tabular}

بالنظر في الجدول رقم (0) نجد ما يلي: 1-توجد فروق جوهرية دالة لصالح الذكور عند مستوى ( (...)، في التوجها الإيجابي نحو الحياة "التفاؤل"، لصالح الذكور • تفسير نتيجة الفرض الأول :

بالنظر في الجدول رقم (0) نجد أن قيمة (ت) دالة عند مستوى ( (...)، بالنسبة لمتغير التوجه الإيجابي نحو الحياة "التفاؤل" ، والنتيجة على هذا النحـو تعني أن الذكور أكثر تفـاؤلا، وهذا يعني أن الفرض قد تحقق كليا، على النحو الذي يمكن تفسيره كما يلي: - إني 


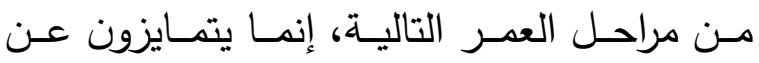
الإناث في كثير من مجالات الحياة العلمية على

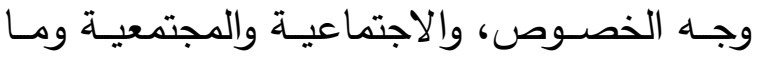

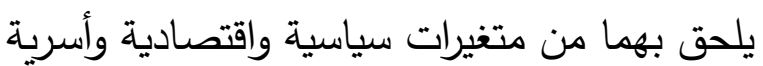
وغيرهـا على وجـه العموم. وليس الأمـر بتمـايز

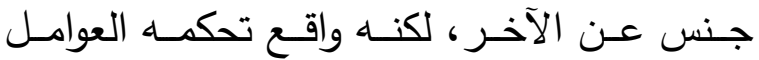
البيولوجية والظروف الاجتماعية والبيئية والأسرية التي تحكم الأنثى وتثيدها، في حين تجعل للذكر في البلاد العربية، وغيرها من بلاد العـالم مجالا أوسع وحرية غير مقيدة، يستطيع القرد من خلالها أن يحقق كثيرًا من النجاحات في مجالات الحياة

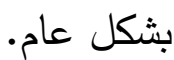

هذا مـع الأخذ في الاعتبار أن هنـاك مـا يتاح للأنثى أن تؤديه، ولا يمكن للذكر مجاراتها

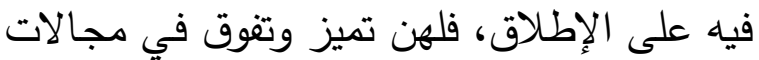

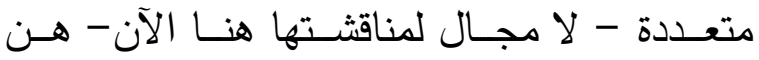

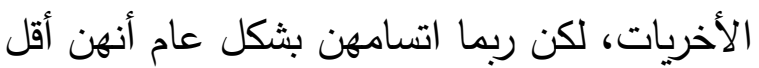

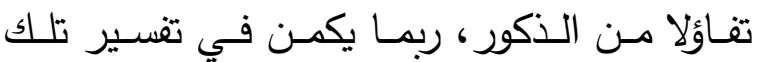
النتيجة، والنتائج التي احتوتها الدراسـات السـابقة والتراث السيكولوجي. واته

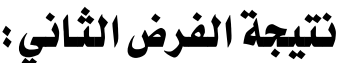

نص الفرض الثاني على ما يلي: "توجد فروق جوهرية بين الجنسين على بنود اختبار التوجه

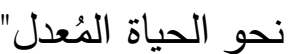

الدراسات هي دراسات كل من (هريدي، بـ99 19

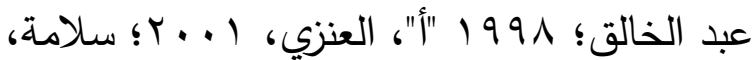
. ( r. ₹

وفي ظن الباحث أن اتسام الذكور بالتفاؤل

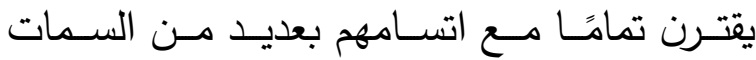
والخصـائص الثخصـية الإيجابيــة التـي وردت بالدراسات السابقة مقارنـة بالإناث، ولعل ما يدعم الإنابه هــا- مـن وجهـة نظـر الباحـث- أن المتفــائلين

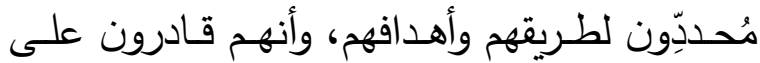

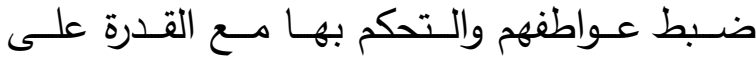
التكيف الذاتي والاجتماعي، والبعد عن التقلبات

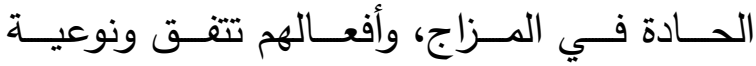
الاستجابات المناسبة للمواقف التي يمرون بها، وهم يتسمون بالأمل ويحسون بالهناء الثخصي، كما أنهم انبساطيون ومفعمون بالحيوية والنشاط. وبعـد هـل يمكن القـول، وفقَّا لمـا جـاء ولهاء بالتراث النظري السيكولوجي والدراسـات السـابقة، أن الذكور موضوع الدراسة - في مجال الدقارنة

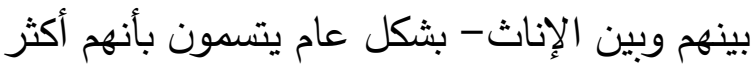

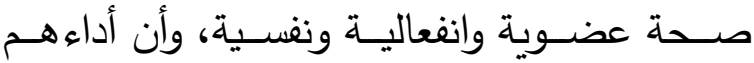
المهنـي والـوظيفي، وكـــلك الأكساديمي، وأنهـ يدركون الضغوط ويتعاملون معها بشكل أفضل. إن الثــواهد التاريخيـة والحياتيــة ونتــائج

الدراسات التجريبية فيها ما يدعم كثيرًا من القول السابق، وما يراه الباحث في هذا الصدد أن الذكور المراهتين الآن، في مرحلة الرشد لاحقًا، وما يليها لياه 
جدول رقم (†) المتوبطات الحسابية والانحرافات المعياربة وقيم "ت"

على بنود اختبار التوجه نحو الحياة المُعدل

\begin{tabular}{|c|c|c|c|c|c|c|c|}
\hline \multirow{2}{*}{ الدلالة } & \multirow{2}{*}{ "ت } & \multicolumn{2}{|c|}{ 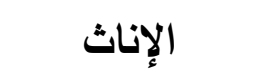 } & \multicolumn{2}{|c|}{ الأكور } & \multirow{2}{*}{ نص البند } & \multirow{2}{*}{ r } \\
\hline & & $\varepsilon$ & r & $\varepsilon$ & s & & \\
\hline. .1 & r. & .9 . & Y.. o & $1.7 r$ & $Y . \Sigma \Lambda$ & 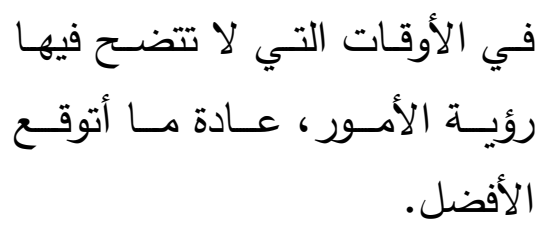 & 1 \\
\hline. .1 & T.. & 1.19 & T.TV & $1 . \leqslant V$ & r.וT & فإذا كان هناك شيء سيحدث لي، لئ & $r$ \\
\hline. .0 & 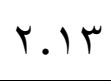 & I.r. & r. 10 & 1.9 & r.T & أنا دائمًا متفائل بشأن مستقبلي. & r \\
\hline غير & $1 . V V$ & $1.1 \varepsilon$ & r.q. & $1 . r$ & Y.TY & نادرًا ما أتوقع أن تسير الأمور في & $\varepsilon$ \\
\hline غير &.$V T$ & 1.11 & Y.O & $1 . \varepsilon r$ & r.TY & نادرًا ما اعتمد على الأشياء الجيدة & 0 \\
\hline غير &.$r$. & 1.10 & T.Y. & $1.1 \mathrm{~V}$ & r.Yr & الصـفة عامـة، أتوقع أن تحدث لي & 1 \\
\hline
\end{tabular}

1- الذكور يتوقعون الأفضـل دومًا في الأوقات

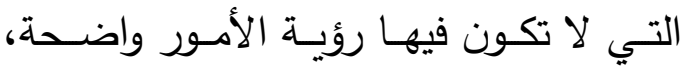
وبمعنى آخـر يتسـم الـكور بتوقـع الأفضـل عندما تكون رؤيـة الأمور غامضة ومبهمة. ب- الـكور لـديهم قناعـة بـأن مـا قدِّرَ لهـم فهـو حادث وواقع لا محالة، وأنه لا تغيير فيه. r- الذكور دائمًا متفائلون بشأن مستقبلهم. والنتيجة على هذا النحو تعني أن الفروق دالة لصالح الذكور في ثلاثة بنود من أصل ستة بنود من اختبار التوجهـ نحو الحياة المُعدل، أي لي أنهح من ناحية الدلالـة الإحصـائية يكونون أكثر تفاؤلا من الإنـاث بنسبة ( •. \%)، وعلى مستوى
بالنظر في الجدول السابق نجد ما يلي: 1- الفـروق دالـة عنـد مسـتوى ( ( . . )، لصـالح الذكور على البندين رقمي (l، r). Y- الفـروق دالـة عنـــ مسـتوى (0. . . ) لصـالح

الذكور أيضًا على البند رقم (ب). r- لا توجد فروق دالة بين الجنسين على البنود أرقام (ع، 0، 7. 7). تفسير نتيجة الفرض الثاني: من واقع البيانـات الإحصائية الواردة بحدول رقمـ (7) نجد الفرض قد تحقق جزئيًا، وبنسبة (. (\%)، ويتضح ذلك مما يلي: 
مسـتقبلهم وتـوقعهم للجيـد مـن الأمسور ولـيس العكس، كذلك فهم على الرغم من هذا، هم نادرًا

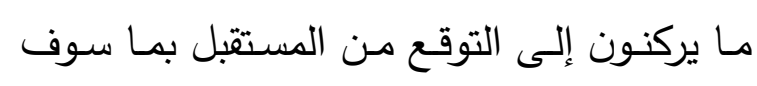

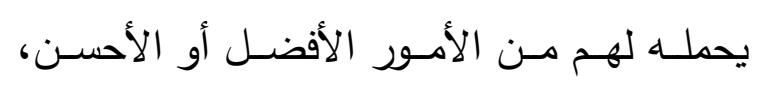

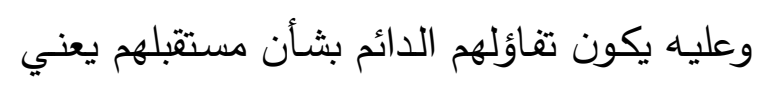

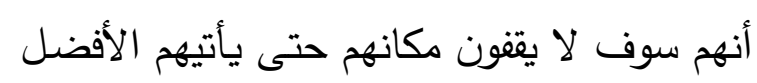
والأحسـن وغير ذلك، بـل هنـاك سـلوك إيجـابي

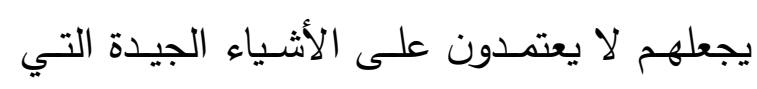
تحدث لهـم، والتي لديهم قناعـة بحدوثها بكثرة

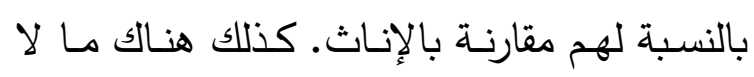

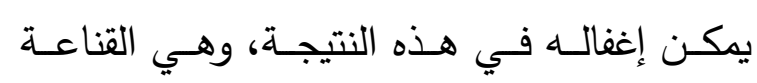

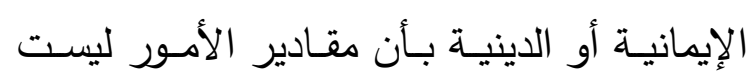

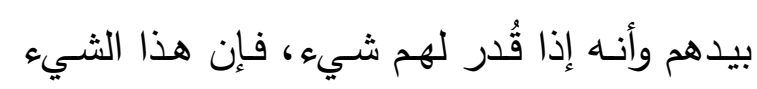
سوف يحدث، وهم هنا، وعلى هذا النحو، أكثر صفاءً نفسيًا وروحيًا مقارنة بالإناث.

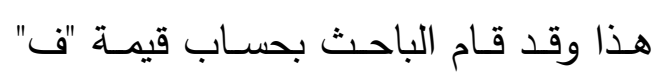

للتعرف إلى دلالة اتجاه الفروق بين الجنسين في

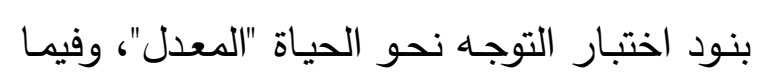
يلي عرض لتلك النتائج:
ارتفــاع المتوســطات فهـم أكثـر تفــاؤلا بنسـبة

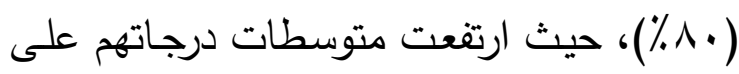
البنـد رقم (0) والـذي يثـير إلى أنهم نـادرًا مـا الـا

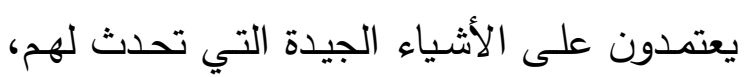
وكذلك على البند رقم (7)، الذي يعني توقعهم أن الأمور الجيدة سوف تحدث لهم أكثر من الأمور السيئة.

في حين ارتفع متوسط درجات الإناث على

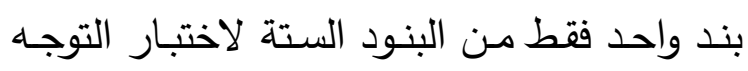
نحو الحياة "المعدل"، وهو البند رقم (ع) والذي يثير إلى أن الإناث لا يتوقعن أن تسير الأمور في صالحهن، وهن بذلك أكثر تثاؤمًا من الذكور

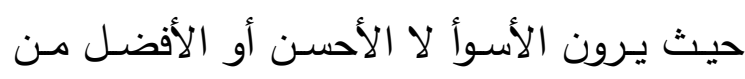
الأمور التي سوف تحدث لهن، فنظرتهن يغلفها التشاؤم لا التفاؤل، وفي هذا دلالة تعني أكثر ما تعني أن الــكور - بثـكل عـام - أكثـر توجهًا إيجابيًا نحو الحياة، فرؤيتهم للأمور التي سوف

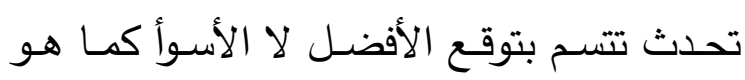
الحـال لدى الإنـاث، ويـرتبط بهـذا تفـاؤلهم بشـأن 
جدول(V) تحليل التباين أحادي الاتجاه بين الجنسين لدلالة الفروق

في بنود اختبار التوجه نحو الحياة المُعدل

\begin{tabular}{|c|c|c|c|c|c|c|}
\hline الدلالة & "قيمة & متوسط & المربعات & الدرجية & مصدر التباين & نص البند \\
\hline$\ldots 1$ & 9.11 & $\begin{array}{l}1.19 \\
1.11\end{array}$ & $\begin{array}{l}1.19 \\
\text { rTo.r. } \\
\text { rVo.rq }\end{array}$ & $\begin{array}{l}1 \\
\text { res } \\
\text { req }\end{array}$ & داخل المجموعات المجموعات & 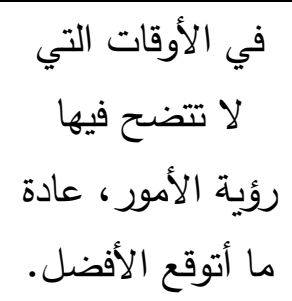 \\
\hline$\ldots 1$ & T.VV & $\begin{array}{l}\text { T.VV } \\
1 . .\end{array}$ & $\begin{array}{l}\text { T.VV } \\
r r q .11 \\
r \leq 0.11\end{array}$ & $\begin{array}{l}1 \\
\text { res } \\
\text { req }\end{array}$ & داخل المجموعات المجموعات & شيء سإذا كيحدث لي، \\
\hline$\ldots 0$ & $\{.00$ & $\begin{array}{l}0.0 . \\
1.51\end{array}$ & 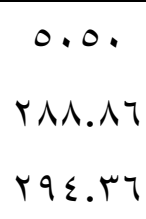 & $\begin{array}{l}1 \\
\text { res } \\
\text { req }\end{array}$ & داخل المجموعات التجموعات & بشأن دائمًا متفائل \\
\hline غير دال & T.I\& & $\begin{array}{l}r . .1 \\
. .91\end{array}$ & 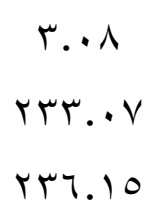 & 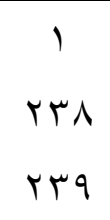 & بين المجموعات التبات المجموعات & تسير الأمور في أتوقع أن \\
\hline غير دال & .04 & $\begin{array}{l}. .74 \\
1.4 \varepsilon\end{array}$ & $\begin{array}{l}. .74 \\
\text { Y97.Y } \\
97 . \leqslant Y\end{array}$ & $\begin{array}{l}\text { i } \\
\text { rta } \\
\text { rta }\end{array}$ & داخل المجموعات المجموعات & الأشياء الجيدة التيد التيد على \\
\hline غير دال & $\ldots 0$ & $\begin{array}{l}\ldots .0 \\
1 . .9\end{array}$ & $\begin{array}{l}. .00 \\
\text { ro9.0r } \\
\text { ro9.01 }\end{array}$ & $\begin{array}{l}1 \\
\text { res } \\
r \text { ra }\end{array}$ & داخل المجموعات المجموعات & بصفة عامة، أتوقع \\
\hline
\end{tabular}

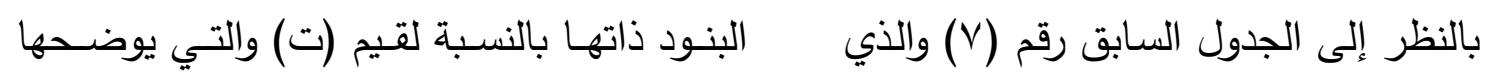

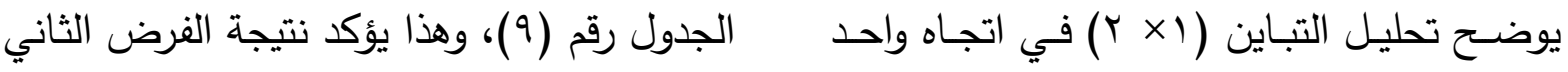

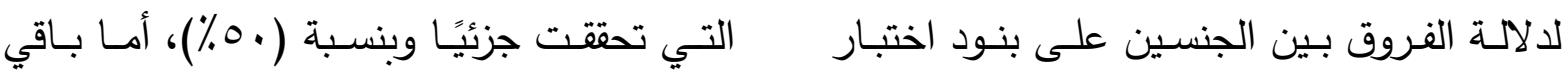

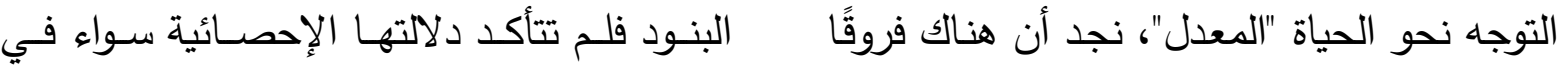

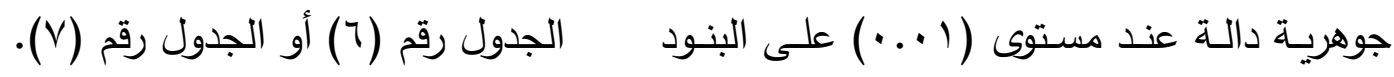

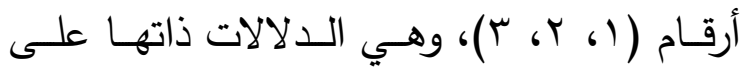


بطريقة "الفاريماكس" "لكايزر"، وقد اعتبر التشبع الجوهري بالعامل > هب . .

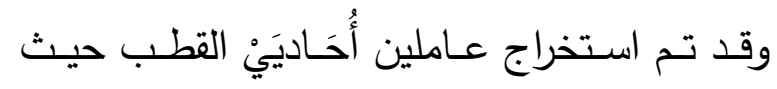
احتويـا على تثـبعات جوهريــة موجبـة، بحيـث

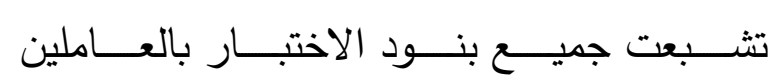

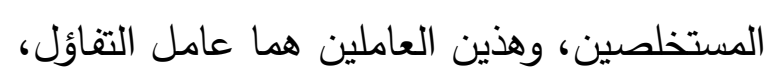
وعامل التشاؤم، وفيما يلي عرض لهما:

\section{العامل الأول : عـامل التقاؤل :}

جدول رقم (^)

يوضتح التشبعات الجوهرية على العامل الأول "عامل التفاؤل" لاختبار التوجه نحو الحياة

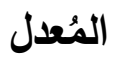

\begin{tabular}{|c|c|c|}
\hline التشبع & البند & رقم \\
\hline •.A & أنا دائما متفائل بشأن مستقبلي. & r \\
\hline$. V 7 \leqslant$ & 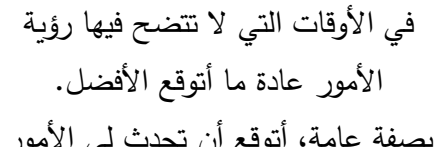 & 1 \\
\hline $.7 Y \wedge$ & الجيدة أكثر من الأمور السيئة. & 7 \\
\hline
\end{tabular}

العامل الثاني : عامل التشاؤم:

جدول رقم (9) يوضح التشبعات الجوهرية على العامل الثاني"عامل التشاؤم" لاختبار التوجه نحو

الحياة المُعدل

\begin{tabular}{|c|c|c|}
\hline التشبع & البند & رقم \\
\hline . & نادرا ما أتوقع أن تسير الأمور في & $\varepsilon$ \\
\hline$\because \vee \vee \varepsilon$ & إذا كان هناك شيء سيحدث لي، & r \\
\hline ع & نادرا ما أعتمد على الأشياء الجيدة & 0 \\
\hline
\end{tabular}

وبعد فالنتيجـة على النحـو الذي جـاءت

عليه تتفق مـع الدراسات السـابقة التي تم تتاولها في الفرض الأول، فالذكور أكثر توجهًا إيجابيًا نحو الحياة من الإنـاث (الفرق دال عند مستوى ( . . )، وبالتالي هم أكثر تفاؤلا. كذلك فالنتيجة تعد إضـافة جديدة في مجال علم النفس بصفة عامـة، وفي مجـال علم النفس الإيجابي بصـفة خاصة، إذ لم يجد الباحث - حسب حدود علمه - دراسة عربية أو أجنبية أتت بمثل النتائج التي أكدتها نتيجة الفرض الحالي. وبعد ووفق التعريـف الذي يتبنـاه الباحث للتوجه الإيجابي نحو الحياة في الدراسـة الحالية،

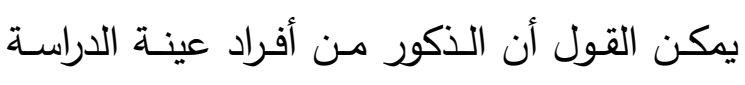
الحاليـة يتسـون بـأن لديهم رؤيسة ذاتيـة إيجابيـة واستعدادًا كامنًا - غير محدود بشروط معينة -

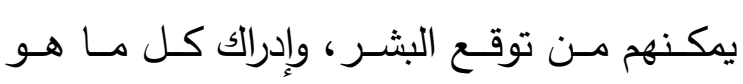

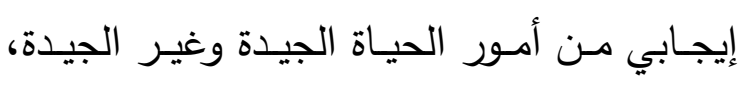
وذلك بالنسبة للحاضر الحالي والمستقبل القادم.

\section{نتيجة الفرض الثالث}

نص الفرض الثالث على ما يلي: "التفاؤل والتثاؤم سمتان يمكن قياسهما بنجاح بوساطة اختبار التوجه نحو الحياة المعدل". تفسير نتيجة الفرض الثالث:

للتحقـق مـن صـــة الفـرض الثالــث قـام الباحث بحساب الصدق العاملي للاختبار ، وذلك منك بحساب معاملات الارتباطات المتبادلة بين البنود السـتة للاختبـار ، وقـد حُللـت مصسفوفة معـاملات الارتبــاط المتبادلــة بـين البـــود عامليًا بطريقــة المكونـات الأساسية لهوتلينج، وتم تدوير العوامل لاهل 
بينما لم تكن هنالك فروق دالة بينهما على البنود

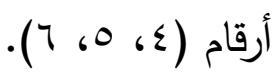

(r) التفاؤل والتشاؤم سمتان يمكن قياسهما بنجاح بوساطة اختبار التوجه نحو الحياة المعدل وتتسق تلك النتائج - كما سبق وتقدم -

في جزء منها مـع نتائج بعض الدراسات السابقة

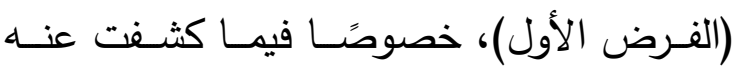
الدراسـات العربية والأجنبية من حيث إن الإناث هن الأكثر تثـاؤمًا بوجـه عـام من الذكور ، في حـين كانــت نتـائج الفـروض الأخـرى جديـدة حسب حدود علم الباحث - في مجـال البحث السـيكولوجي خصوصًَ في مجـال علم الـنفس

$$
\text { الإيجابي والشخصية. }
$$

ثانيا :

تأسيسًا على حاجة مجال القياس النفسي

في البيئـة العربيـة إلىى أداة سـيكولوجية ملائكـة لقياس التفاؤل، سعت الدراسـة الحالية إلى توفير أداة عالميـة ذائعـة الانتشـار في ثقافـات عديـدة لقيـاس التفـاؤل، يمكـن أن يسـتخدمها البـاحثون والاختصـاصـيون النفسـيون فـي مجـال البحـوث الحضــاريـة المقارنـة، وغيرهـا مـن مجـالات علـم الـنفس، والأداة لهـا خـواص عديـدة فهـي تقـيس مفهومًا يُعد من المفاهيم الأساسية والثـائعة في وصف إحدى السـمات الثخصسية وقياسـها وهـو "التفاؤل"، كما أن الأداة تُعد مناسبة لقياس سمة

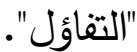

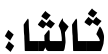

أسفر التحليل العاملي للأداة عن استخراج

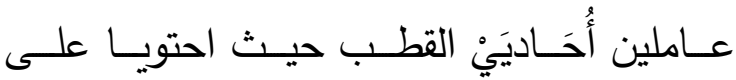

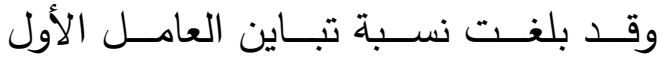

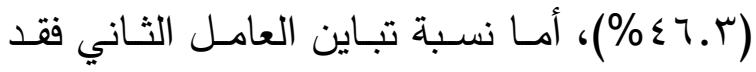
بلغـت (^. ؟ ا \%)، وبلغـت النسـبة الكليـة للتبـاين ( ا ( آ\%\%)، وهـي نسـبة تشـير إلـى أن العوامـل المسـتخرجة تكفي إلى حــ مـا لاسـتيعاب قـدر معقول من التباين.

ونتائج التحليل العاملي على النحو السابق،

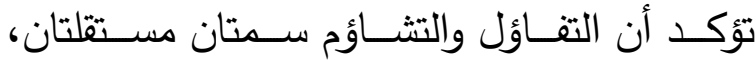
ولكنهــا مترابطتان، وهـا عكس مـا كـان يظـن مؤلفو المقيـاس - كمـا سبق وتقدم - حيث كـان الاعتقـاد أن التفـاؤل والتشــاؤم عبـارة عـن سـمة واحدة، ولكنها ثنائية القطب، أي أن متصـل هذه السمة له قطبان متقابلان متضادان*

\section{تعليق عام على النتائج :}

أو

باستعراض نتائج الدراسة نجد أن الفروض الأول قد تحقق كليا بينما الفرض الثاني قد تحقق لـق جزئيًا من حيث:

(1) وجـود فـروق جوهريــة دالــة لصــالح

الذكور في التوجه الإيجابي نحو الحياة "التفاؤل"

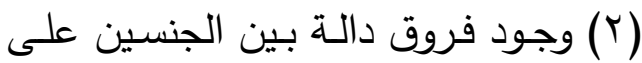

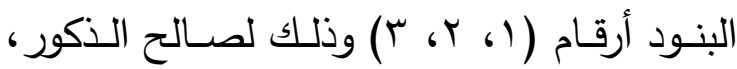

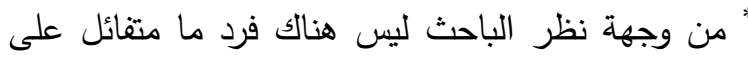
طول الخط، أو متثائم دومًا، ولكنه يجنح تارة هنا وأخرى لهن هناك، وعليه يتفق الباحث مع عدد من الدراسات العربية والأجنبية التي تتاول الباحث بعضًا منها في سياق هذه لئه الدراسة إلى النظر إلى التفاؤل والتثاؤم بوصفهما سمتين ذات استقلال نسبي على الرغم من الارتباط الجوهري

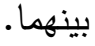


توصيات الدراسة:

في ضـوء مـا أسفرت عنـه نتائج الدراسـة

الحالية، يقترح الباحث الموضوعات التالية:

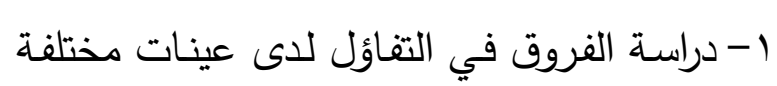

من ذوي الاحتياجات الخاصة من الجنسين.

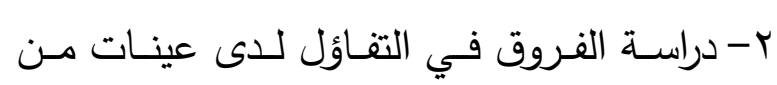

الأدباء والعلماء من الجنسين.

ب- دراســة الفـروق فــي التفـــاؤل لــدى الأزواج

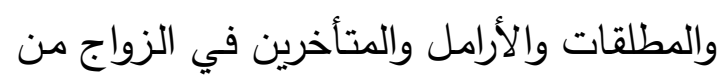

الجنسين، والذين لم ينجبوا أولادًا من الجنسين.

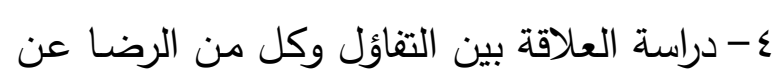

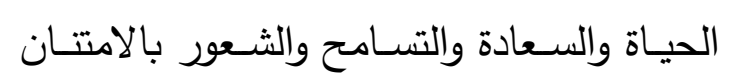

لاى عينات متباينة من الجنسين.

ه- دراسـة الفروق في التفاؤل للى عينات عمريـة

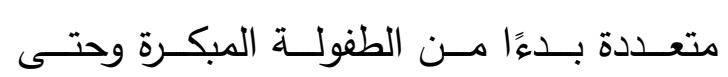

الشيخوخة من الجنسين.

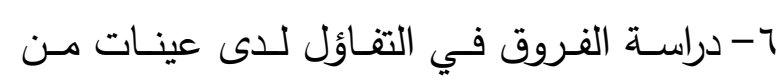

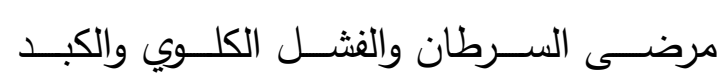

وأصحاب نمط السلوك "أل" من الجنسين.

المراجع

\section{أولا: المراجع العربية}

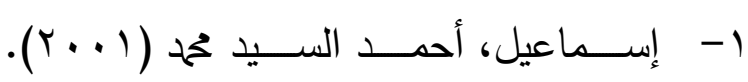

التفاؤل والتثاؤم وبعض المتغيرات النفسية

لـدى عينـة مـن طـلاب جامعـة أم القـرى.

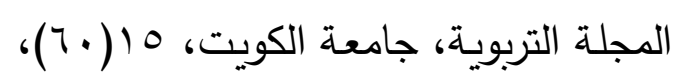

$$
\text { . (1) }-01
$$

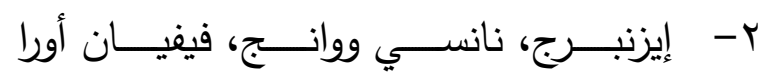

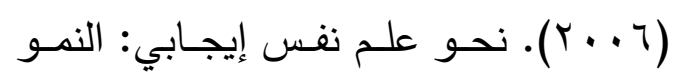

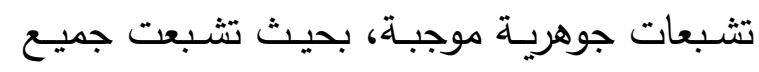
بنود الاختبـار بالعـاملين المستخلصين، وهذان العاملان هما عامل التفاؤل، وعامل التشاؤم.

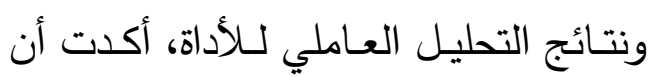

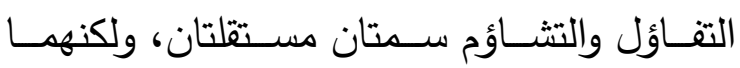

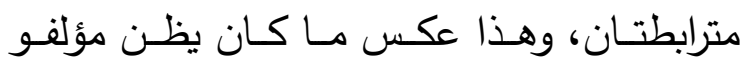
المقياس - كما سبق وتقدم - حيث كان الاعتقاد

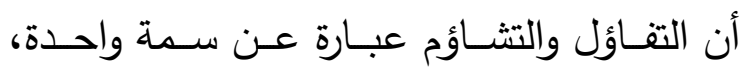

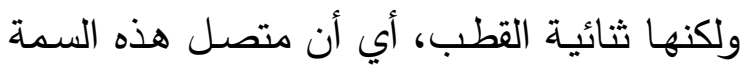
له قطبان متقابلان متضـادان، وأن الدرجة العالية

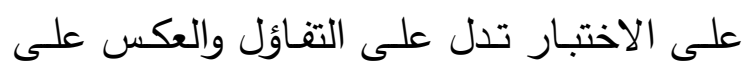
التشـاؤم، بمعنى آخـر كـان يُنظـر إلـى التفــاؤل

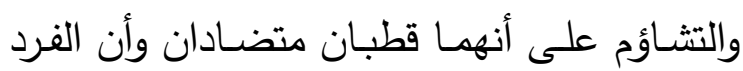

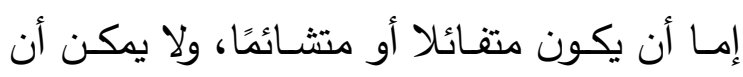
يكون متفائلا ومتثائيًا معًا.

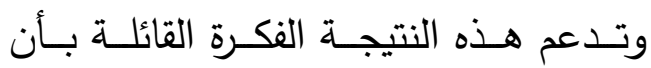
التفاؤل والتثاؤم سمتان مستقلتان استقلالا نسبيًا

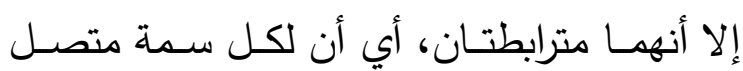

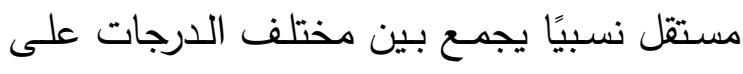

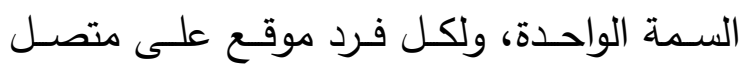
التفاؤل، مستقلا عن مركزه على متصل التشاؤم،

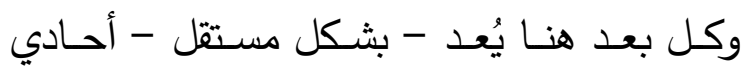
القطب، يبدأ من أقل درجـة على التفاؤل (وقد ذكون درجـة صفر )، إلى أقصسى درجة، والأمـر

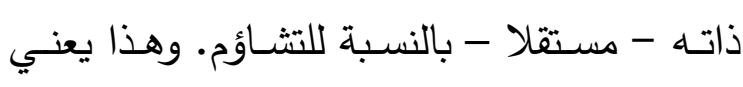

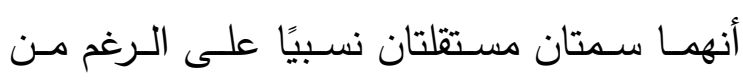

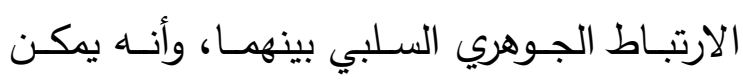

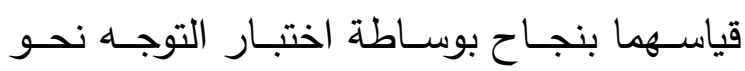
الحياة "المعدل". 


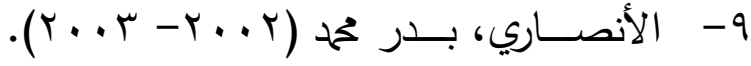

التقاؤل والتشاؤم: قياسهما وعلاقتهما ببعض

متغيـرات الشخصـية لـدى طـلاب جامعــة

الكويـــ، حوليــات كليــة الآداب والعلــوم

الاجتماعية-جامعة الكويت، الحولية (بr)،

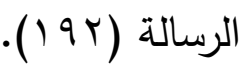

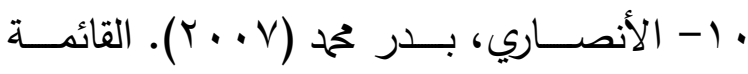
العربيـة للتفـاؤل والتشـاؤم: نتائج مـن ثـاني عشرة دولـة عربيـة، القـاهرة: مجلـة دراسـات

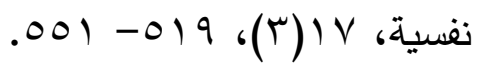
1ا- البعلبكي، منير (r/9 ()). المورد، بيروت: دار العلم للملايين. Y T - الحفني، عبد المنعم ( 99 ( ). موسوعة علم الـنفس والتحليـل النفسي، طـ (ع)، القـاهرة:

$$
\text { مكتبة مدبولي. }
$$

با - الخضـر ، عثمـان حمـود (999 1). التفـاؤل والتشــاؤم والأداء الـوظيفي. المجلــة العربيـة

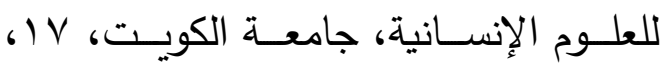

$$
. r \leq r-r) \leqslant 6(T r)
$$

ع ا- العنزي، فريح عويد والمشعان، عويد سلطان المشعان (9 (991 ). العلاقـة بين الشخصية الفصامية والتفاؤل والتشاؤم، القاهرة: المجلة

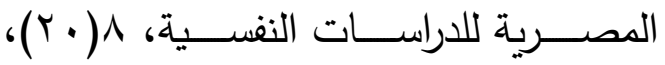

$$
.104-1 \text { KA }
$$

10- العنـزي، فـريح عويـــ (1 + . ب). الثــعور

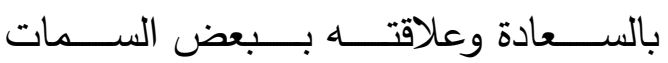
الشخصـية: دراســة ارتباطيــة مقارنــة بـين الـذكور والإنـاث، القـاهرة: مجلـة دراسـات

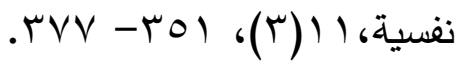

الاجتمـاعي والإسـهامات الثقافيـة، ترجمـة: نادية شريف، في: صفاء الأعسر وآخرين: ســــولوجية القــوى الإنســانية: تســاؤلات أساسـية وتوجهـات مســقبلية لعلـم الـنفس إنس الإيجابي، القاهرة: المجلس الأعلى للثقافة. r- أنتوني، روبرت (0. . ب). مـا وراء التفكير الإيجـابي، ترجمـة: مكتبـة جريـر، السعودية:

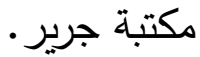
ع- أنـيس، إبـراهيم وآخـرون (9VY I ). المعجم الوسـيط، ط (Y)، الجزء (Y)، القـاهرة: دار المعارف 0- الأنصــاري، بــدر تحمد (991 ). التفــاؤل والتشــاؤم: المفهـوم والقيــاس والمتعلقــات. جامعة الكويت: مجلس النشر العلمي: لجنة التأليف والتعريب والنشر •

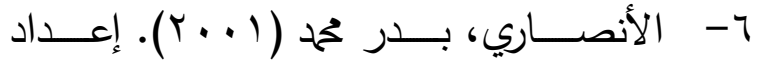
مقياس التفاؤل غير الواقعي لدى عينـة من الطلبة والطالبات في الكويت. القاهرة: مجلة

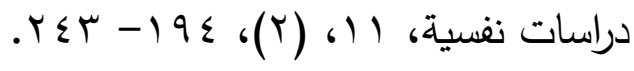
- الأنصــاري، بــدر تحمد (Y . . ب"أ"). إعــداد صـورة عربيـة لمقيـاس التوجـهـ نحـو الحيـاة

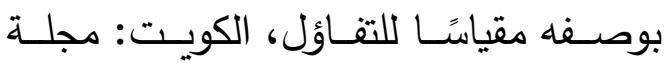

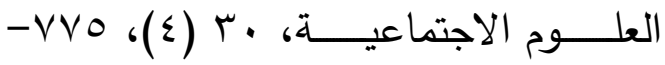
.$A 1 Y$

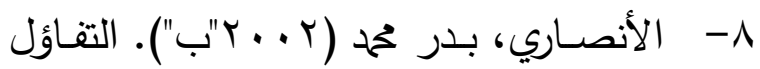
غيـر الــواقعي وعلاقتــهـ بـبعض المتغيـرات الشخصـية لـدى طـلاب جامعـة الكويـــ، مجلـة العلـوم التربويــة والنفسـية- جامعـة

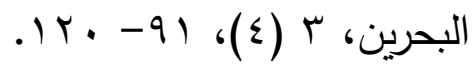


النفسـي، الجـزء (V)، القـاهرة: دار النهضــة

$$
\text { العربية. }
$$

r r - خليفة، عبد اللطيف خحم، ورضوان، شعبان جاب الله (991 (19). بعض سمات الثخصية

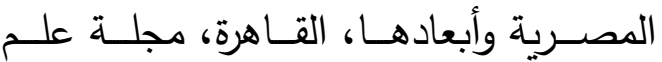

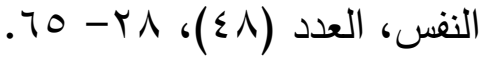

rr- دســوقي، كمـال (911 (1). ذخيـرة علـوم النفس، المجلد (1)، القـاهرة: الـدار الدوليـة للنشر والتوزيع. گ צ- دســوقي، كمــال ( •99 1). ذخيـرة علـوم النفس، المجلد (Y)، القاهرة: وكالة الأهرام للتوزبح.

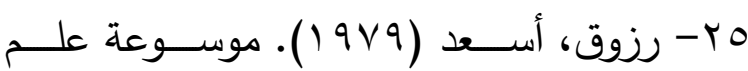
النفس، طـ (ץ)، بيـروت: المؤسســة العربيـة

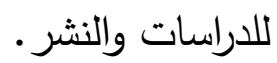
جr- سلامة، فاطمة عياد (ع . . ب). العلاقة بين التفاؤل والتشـاؤم والتقدير الذاتي للأعـراض الجسمية والنفسية، القاهرة: المجلة المصرية

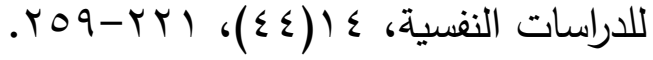

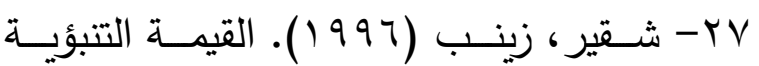
لـبعض الحـالات الكلينيكيـة المختلفـة مـن الطمأنينـة النفسـية والتفـاؤل والتشـاؤم وقلق الموت، مجلة كلية التربية - جامعة طنطا،

$$
\text { .rะ.-rqT، (rT) }
$$

^r - شكري، مايسة محه (9 9 ( ). التفاؤل والتشاؤم وعلاقتهما بأساليب مواجهة المشقة، القاهرة:

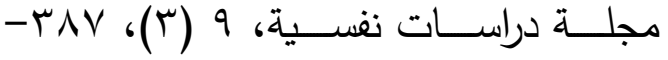
.517
1 ا - المشـعان، عويـد سلطان (999 (1). التفـاؤل والتثـاؤم وعلاقتهمــا بالإضــرابات النفسـية الجسمية والرضا الوظيفي لاى الموظفين في القطـاع الحكـومي بدولـة الكويـــ، القـاهرة: المـؤتمر الـدولي السـادس لمركـز الإرشـاد النفسـي - جامعـة عـين شـمس، (ص ص $\cdot(9 V \cdot-9 \leqslant V$ IV والتشـاؤم وعلاقتهمـا بالاضـطرابات النفسـية الجسمية وضغوط أحداث الحياة لدى طلاب الجامعة، القاهرة: مجلة دراسات النفسية، • $.0 \mathrm{rr}-0.0$ ( $)$

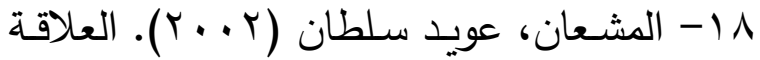
بــين الرضــا الـوظيفي وكـل مــن التفــاؤل والتشــاؤم والاضـــرابات النفسـية الجسـمية لدى الموظفين في القطاع الحكومي بدولـة الكويـت. المجلـة العربيـة للعـوم الإنسـانية،

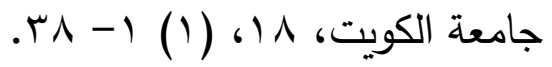

9 1 - جـابر ، عبـد الحميـد جـابر وكفـافي، عـلاء الدين ( • 99 (1). معجم علم النفس والطب النفسـي، الجـزء (ب)، القـاهرة: دار النهضــة

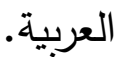
•r- جـابر ، عبد الحميـد جـابر وكفـافي، عـلاء الدين (Y99 ( I)). معجم علم النفس والطب النفسـي، الجزيء (0)، القـاهرة: دار النهضــة

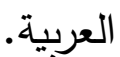
ا الY- جـابر ، عبد الحميد جـابر وكفـافي، عـلاء الدين (990 (1). معجم علم النفس والطب 
القـاهرة: مجلـة دراسـات نفسية، 0 (ب)؛ .)

V V- عبد العزيز، مصطفى تحمد (911 ()). مشكلة الاستذكار كما تبدو في رسوم وكتابات عينة مـن المـراهقين، القـاهرة: المـؤتمر الـدولي

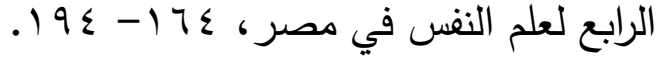
رب- عبــــ اللطيــف، حســن وحمــادة، لولـــوه (991 ( ) ). التفــاؤل والتشـــاؤم وعلاقتهمهــا ببعـدي الشخصـية: الانبسـاط والعصـابية، مجلة العلوم الاجتماعيـة- جامعـة الكويــ، . 1 .

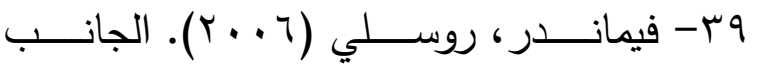
المضـيء والجانـب المظلـم في سـيكولوجية القـوى الإنســانية: مثــال مـن سـيكولوجية المسنين، ترجمة: عـلاء الدين كفافي، في: صـفاء الأعسر وآخرين: سيكولوجية القوى الإنســانية: تســاؤلات أساســية وتوجهـات مسـتقبلية لعــم الـنفس الإيجـابي، القـاهرة: المجلس الأعلى للثقافة. • ع- عحد، رجب علي شعبان (1 . . ب). الانجاز الأكــاديمي وعلاقتــــه بالتشـــاؤم والتــــاؤل والدافعية وأسـاليب مواجهة المشكلات لدى لدى طالبـات الجامعــة "دراســة تتبؤيسة، القـاهرة: المجلـة المصـرية للدراسـات النفسـية، 11

$$
\cdot r \cdot r-170 \cdot(r r)
$$

إ- مــراد، صــلاح أحمـد وأحمـد، تحمد عــامر ( ( . . ( . . أنمـاط التعلم والتفكير وعلاقتها بالتفــاؤل والتشـــاؤم لطلبـــة التخصصـــات

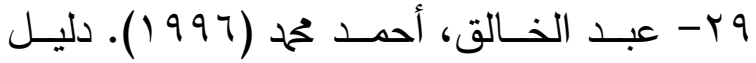
تعليمـات القائمــة العربيـة للتفـاؤل والتشــاؤم، الإسكندرية: دار المعرفة الجامعية.

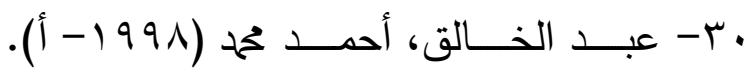
التفــاؤل والتشــاؤم وقلــق المــوت: دراســـة عامليـة، القـاهرة: مجلـة دراسـات نفسـية، 1

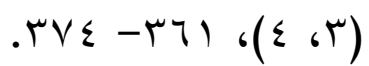
اس- عبــد الخــالق، أحمــد محهد (9919 1- ب). التفــاؤل وصـــة الجســ: دراســة عامليــة، الكويت: مجلة العلوم الاجتماعية، بr (Y)، $.7 r-\leqslant 0$

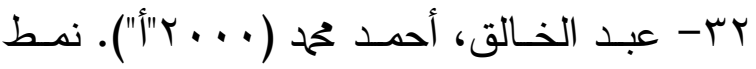
الســلوك "ا"ا": دراســـة لــبعض الارتباطــات الاجتماعية والنفسية، القاهرة: مجلة دراسات

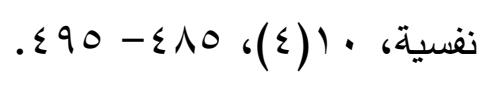

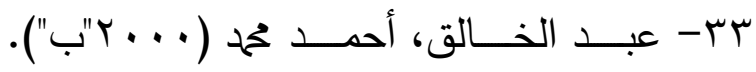
التفـاؤل والتشـاؤم: عرض لدراسـات عربيـة، القاهرة: مجلة علم النفس، العدد (7ه)، ج.$T V$ ع ז- عبد الخالق، أحمد حمد ومراد، صـلاح أحمد

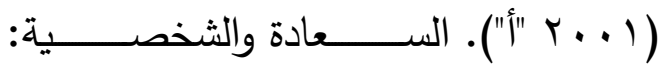
الارتباطــات والمنبئــات، القـــاهرة: مجلـــة

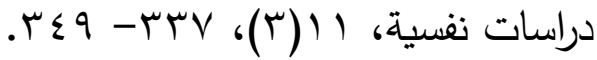
هب- عبد الخالق، أحمد ححمد ومراد، صـلاح أحمد

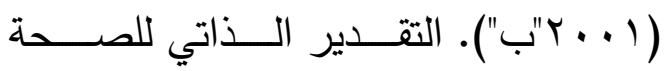
النفسية: دراسـة لأهم منبئاته، القاهرة: مجلة

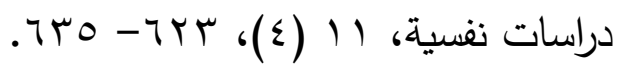
דب- عبد الخالق، أحمد حمد (0 . . ץ). المقياس العربـي للتفـاؤل والتشـاؤم: نتـائج مصـرية، 
partum depression, Cognitive Therapy and Research, 11, 449 - 462.

6. Carver, C.S., Pozo, C., Harris, S.D., Noriega, V., Scheier M.F., Robinson, D.S., Ketcham, A.S., Moffat, F.L.Jr, \& Clark, K.C. (1993). How coping mediates the effect of optimism on distress: A study of women with early stage breast cancer, Journal of Personality and Social Psychology, 65(2): 375- 390.

7. Chang, E.C. (1996). Cultural difference in optimism, pessimism and coping: predictors of subsequent adjustment in Asian American and Caucasian American college students. Journal of Counseling Psychology, 43, 113 - 123.

8. Chang, E.C., Maydeu-Olivares, A., \& D'Zurila, T.J. (1997). Optimism and pessimism as partially independent constructs: Relationship to positive and negative affectivity and psychologically well-being. Personality and Individual Differences, 23, 433 -440.

9. Chang, E.C. (Ed), (2001). Optimism \& pessimism: Implications for theory, research, and practice, (pp. 189-216). Washington, DC, US: American Psychological Association, xxi, 395 pp. doi: $10.1037 / 10385-009$

10. Chang, E.C. (2002). Optimismpessimism and stress appraisal: Testing a cognitive interactive model of psychological adjustment in adults. Cognitive Therapy and Research, 26(5):675-690.

11. Cheng, S. T., \& Hamid, N. P. (1997). Dispositional optimism in Chinese people: What does the Life Orientation Test measure? International Journal of Psychology, 32:15-22.

12. Creed, P. A., Patton, W., and Barturn, D. (2002). Multidimensional properties of the LOT-R: Effects of optimism and pessimism on career and well- being related variables in

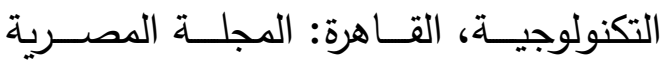

$$
\begin{aligned}
& \text { للدراسات النفسية، ال|(Yr)، | |- (؟. }
\end{aligned}
$$

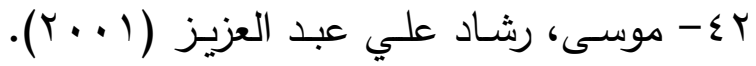

$$
\begin{aligned}
& \text { معجم الصـحة النفسية المعاصـر، القـاهرة: } \\
& \text { الفاروق الحديثة للطباعة والنشر • }
\end{aligned}
$$

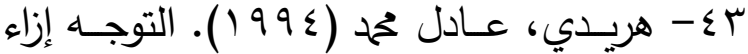

$$
\begin{aligned}
& \text { الحياة وعلاقته بالاعتداد بالذات وبالأعراض } \\
& \text { الجسـمية والحـالات المزاجيـة اليوميـة في } \\
& \text { ضـوء بعض المتغيرات، مجلة بحوث كلية }
\end{aligned}
$$

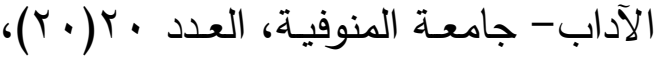

$$
\begin{aligned}
& .11 T-V V
\end{aligned}
$$

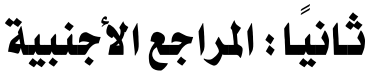

1. Apinwall, L.G., \& Taylor, S.E. (1992). Modeling cognitive adaptation: A longitudinal investigation of the impact of individual differences and coping on college adjustment and performance. Journal of personality and Social Psychology, 63, 711- 723.

2. Boland, A. \& Cappeliez, P. (1997). Optimism and neuroticism of predictors of coping and adaptation in older woman. Personality\& individual Differences. 22, 909-919.

3. Brebner, J., Donald, J., Kirby, N. \& Ward, L. (1995). Relationships between happiness and personality, Personality and Individual Differences, 19(2):251-258.

4. Brissette; Scheier, M.F., and Carver, C.S. (2002). The role of optimism and social network development, coping, and psychological adjustment during a life transition. Journal of Personality and Social Personality, 82, 102- 111.

5. Carver, C. S., \& Gaines, J. G. (1987). Optimism, pessimism and post- 
reactivity. Personality and Individual Differences, 19 (6): 827 - 839.

22. Hickman, S.E; Watson, P.J., \& Morris, R. J. (1996). Optimism, pessimism and complexity of narcissism. Personality and Individual Differences, 20 (4):521-525.

23. Hills, P., and Argyle, M. (2001). Emotional stability as a major dimension of happiness. www.sciencedirect.com/science?

24. Huitt, W. (1996). Optimism and enthusiasm. Educational Psychology Interactive. Valdosta, GA:Valdosta State University. Retrived from: http://chiron.valdsota.edu/whuitt/col/a ffsys/optenth.html

25. Huitt, W. (2005). Important affective dispositions: Optimism, enthusiasm, and empathy. Educational Psychology Interactive. Valdosta, GA: Valdosta State University. Retrived from:

http://chiron.valdsota.edu/whuitt/col/a ffsys/optenth.html

26. Kiyak, H.A., Vitaliano, P.P., \& Crinean, J. (1988). Patients expectations as predictors of orthognathic surgery outcomes. Health Psychology, 7, 251-268.

27. Lai, J. C. L. (1997). Relative predictive power of the optimism versus the pessimism index of a Chinese version of the Life Orientation Test.

www.findarticles.com/p/articles/mi_q a3645/199707/ai_n8762013

28. Lai, J.C.L., \& Wong, W.S. (1998). Optimism and coping with unemployment among Hong Kong Chinese Women. Journal of Research in Personality, 32(4): 454-479.

29. Lai, J.C.L., \& Yue, X. (2000). Measuring optimism in Hong Kong and mainland Chinese with revised Life Orientation Test. Personality and Individual Differences, 28, 781- 796.

30. Lounsbury, J.W., Park S-H., Sundstrom E, Jeanine M. Williamson adolescents. Journal of Career Assessment, 10 (1): 42- 61.

13. Davis, S.F., Miller, K.M., Johnson, D., McAuley, K. and Dinges, D. (1992). The relationship between optimism, loneliness and death anxiety. Bulletin of Psychonomic Society. 30(135-136).

14. Dember, W.N., \& Brooks, J.A. (1989). A new instrument for measuring optimism and pessimism: Test re-test reliability and relations with happiness and religious commitment. Bulletin of the Psychonomic Society, 356-366.

15. Fischer, M., \& Leitenberg, H. (1989). Optimism and pessimism in elementary school aged children. Child Development, 57, 241-248.

16. Fontaine, K. R. (1994). Effect of dispositional optimism on comparative risk perceptions for developing AIDS. Psychological Reports, 74 (3.PT1), 843-846.

17. Funck, S.C., \& Houston, B.K. (1987).A critical analysis of the Hardiness Scale's validity and utility. Journal of Personality and Social Psychology, 53, 572- 578.

18. Gillinder, B., and Brown, S. L. (2005). Optimism, coping, and emotional well-being in Cardica patients. British Journal of Health Psychology 10 (1), 57 - 70.

19. Hale, W.D.; Fiedler, L. R., \& Cochran, C. D. (1992). The Revised Generalized Expectancy for Success Scale: A validity and reliability study. Journal of Clinical Psychology, 48, 517- 521.

20. Harju, B., and Bolen, L. (1998). The effects of optimism on coping and perceived quality of life of college students. Journal of Social Behavior and Personality, 13 (2), 185 - 200.

21. Hart, K.E., \& Hintter, J.B. (1995). Optimism and pessimism: Association to coping and anger- 
38. Mehraian, A., \& Ljunggren, E. (1997). Dimensionality and content of optimism-pessimism analyzed in terms of the PAD temperament model. Personality and Individual Differences, 23, 729-76-37.

39. Mook, J., Kleijn, W., \& Ploeg, H.M. (1992). Positively and negatively worded items in a self-reported measure of dispositional optimism. Psychological Reports, 71, 275-278.

40. Nakano, K. (2004). Psychometric properties of the Life Orienlation Test-Revised in samples of Japanese students.Psychological Reports. (3pt):849-855.

41. O' Rourke, N. (2003). Biased responding, neuroticism, and perceived control among older adult. Current Research in Psychology, 9 (5):60-74.

42. Plomin, R., Scheier, M.F., Bergeman, C.S., \& Pedersen, N. (1993). Optimism, pessimism, and mental health: A twin/adoption analysis. Personality and Individual Differences, 13(8): 921 - 930.

43. Reilley, S.P., Geers, A.L., Lindsay, D.L., Deronde, L., \& Dember, W.N. (2005). Convergence and predictive validity in measures of optimism and pessimism: Sequential studies. Journal of Current Psychology, 24(1):43-59.

44. Robbins, A.S., Spence, J.T., \& Clark, H. (1991). Psychological determinants of health and performance: The tangled web of desirable and undesirable characteristics. Journal of Personality and Social Psychology, 61(5):755765 .

45. Robinson-Whelen, S., Kim, C., MacCllum, R.C., \& Kiecolt-Glaser, J.K. (1997). Distinguishing optimism from pessimism in older adults: Is it more important to be optimistic or not to be pessimistic? Journal of
Anne E. Pemberton (2004). Personality, Career Satisfaction, and Life Satisfaction: Test of a Directional Model Journal of Career Assessment, 12(4):395-406.

31. Lyons, A.C. \& Chamberlain, K. (1998). Daily events and physical symptoms: Effects of event type, optimism, pessimism, and health behaviors. Current Research in Social Psychology, 3(8): 88- 102.

32. Mahler, H.I.M, \& Kulik, J.A. (2000).Optimism- pessimism and recovery from coronary by pass surgery: Prediction of affect, pain and functional status. Journal of Psychology, Health and Medicine, 5(4): 347-358.

33. Malik, S. and Rehman, G. (2003). Relationship of optimism/ pessimism, vulnerability to stress and academic achievement of college students. www.adultstudent.com/eds/articles/o pti-pess-html

34. Marshall, G.N., \& Lang, E.L., (1990). Optimism, self-mastery, and symptoms of depression in women professionals. Journal of Personality and Social Psychology, 59, 132- 139.

35. Marshall, G.N., Wortman, C.B., Kusulas, J.W., Hervig, L.K., \& Vickers, R.R. (1992). Distinguishing optimism from pessimism: Relations to Fundamental dimensions of mood and personality. Journal of Personality and Social Psychology, 62, 1067-1074.

36. Marshall, G.N., Wortman, Vichers, R.R. C.B., Kusulas, J.W. \& Hervig, L.K. (1994). The five-factor model of personality as a framework for personality health research. Journal of Personality and Social Psychology, 67, 278- 286.

37. Mc Gregor, B.A., et al., (2004). Optimism, perceived risk of breast cancer, and cancer worry among a community-based sample of woman. Health Psychology, 23 (4): 339 - 344. 
53. Seligman, M.E.P., \& Mihaly, C. (2000). Positive psychology: An introduction. American Psychologist, 55(1): 5-14.

54. Seligman, M.E.P. (2002). Positive psychology, positive prevention, and positive therapy. In C.R. Snyder \& S.J. Lopez (Eds.), Handbook of Positive Psychology (pp. 3-9). New York: Oxford University Press.

55. Seligman M.E.P. (2003). Does suffering trump happiness?

www.authentichappiness.sas.upenn.e du/newsletter.aspx ?id=52

56. Seligman, M.E.P., Steen, A.T., Park, N., \& Peterson, C. (2005). Positive psychology progress: Empirical validation of interventions, American Psychologist, 60(5): 410-421.

57. Shepperd, J.A., Maroto, J.J., \& Pbert, L.A. (1996). Dispositional optimism as a predictor of health changes among cardiac patients. Journal of Research in Personality, 30, 517- 534.

58. Sitz, E.H. \& Poche, N. (2002). Gender differences in the relationship between optimism and perceived stress.

http://elearinghouse.mwcc.edu/manus cripts/344.asp

59. Smith, T.W., Pope, M.K., Rohdewalt, F., \& Poulton, J.L. (1989). Optimism, neuroticism, coping and symptom reports: An alternative interpretation of the Life Orientation Test. Journal of Personality and Social Psychology, 56: 460-468.

60. Stipek, D.J. (1981) Socialmotivational development in first grade. Contemporary Educational Psychology, 6, 33- 45.

61. Taylor, S.E., Kemeny, M.E., Aspiwall, L.G., Schneider, S.G., Rodriquez, R. \& Herber, M. (1992). Optimism, coping, psychological distress, and high-risk sexual behavior among men at risk for AIDS. Journal of Personality and Social Psychology, 63, 460- 473.
Personality and Social Psychology, 73(6): 1345- 1353.

46. Rohrer, T. (2005). Positive Psychology: The future of psychology?

www.successworkscoaching.com/Res ources/futureOfPsych.pdf

47. Scheier, M.F. \& Carver, C.S. (1985). Optimism, coping and health: Assessment and implications of generalized outcome expectancies. Health Psychology, 4, 219- 247.

48. Scheier, M.F. \& Carver, C.S. (1987). Dispositional optimism and physical well-being: The influence of generalized outcome expectations on health. Journal of Personality, 55, 169- 210.

49. Scheier, M.F., Mattews, K.A., Owens, J.F., Magovem, G.J., Lefebvre, R.C., Abbott, R.A., \& Carver, C.S. (1989). Dispositional optimism and recovery from coronary artery by pass surgery: The beneficial effects on physical and psychological well-being. Journal of Personality and Social Psychology, 57, 1024 -1040.

50. Scheier, M.F., and Carver, C. S. (1992). Effects of optimism on psychological and physical wellbeing: Theoretical over-view and empirical update. Cognitive Therapy and Research, 16, $201-228$.

51. Scheier, M.F., Carver, C.S., \& Bridges, M.W. (1994). Distinguishing optimism from neuroticism (and trait anxiety, self-mastery and selfesteem): A re-evaluation of the Life Orientation Test. Journal of Personality and Social Psychology, 67, 1063 -1078.

52. Segerstrom, S.C., Taylor, S.E., Kemeny, M.E., \& Fahey, J.L. (1998). Optimism is associated with mood, coping, and immune change in response to stress. Journal of Personality and Social Psychology, 74, 1646- 1655. 
65. Vittero, J. (2001). Personality traits and subjective well-being: Emotional stability, not extraversion, is probably the important predictor. Personality and individual Differences, 6(15): 903-914.

66. Williams, D.G. (1992).Dispositional optimism, neuroticism, susceptibility to health problems: Conclusions from a community- wide sample. Journal of Behavioral Medicine, 10, 481-500.

67. Yates, S.M. (2000). Student optimism and pessimism during the transition to co-education. Paper presented at the Australian Association for Research in Education Conference, Sydney. www.aare.edu.au/00pap/yat00439.ht $\underline{\mathrm{m}}$
62. Treharne, G.J., Lyons, A.C., \& Tupling. R.E. (2001). The effects of optimism, pessimism, social support, and mood on the lagged relationship between daily stress and symptoms. Current Research in Social Psychology. 7(5):60-82.

63. Treichel, J.A. (2006). Teen personality traits can predict adult mental health. American Psychiatric Association, 41(12): 26-27.

64. Vautier, S., Raufaste, E., \& Cariou, M. (2003). Dimensionality of the Revised Life Orientation Test and the status of filler items. International Journal of Psychology 38 (6): 390400. 